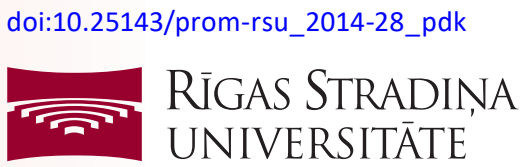

\title{
Aleksandrs Derjabo
}

\author{
SEJAS, GALVAS \\ UN KAKLA ĀDAS \\ BAZĀLO ŠŪNU \\ VĒŽA ĀRSTĒŠANA
}

Promocijas darba kopsavilkums medicinas doktora zinātniskā grāda iegūšanai

$$
\text { Specialitāte - onkoloǵija }
$$

Rīga, 2014 


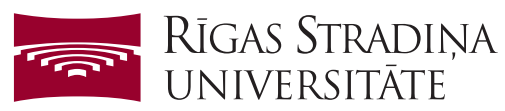

Aleksandrs Derjabo

\title{
SEJAS, GALVAS UN KAKLA ĀDAS BAZĀLO ŠŪNU VĒŽA ĀRSTĒŠANA
}

\author{
Promocijas darba kopsavilkums \\ medicīnas doktora zinātniskā grāda iegūšanai
}

Specialitāte - onkolog̣ija

$$
\text { Rīga, } 2014
$$


Promocijas darbs izstrādāts Rīgas Austrumu klīniskās universitātes slimnīcas Latvijas Onkologijas centrā (RAKUS LOC). Pētījums apstiprināts ar Rīgas Stradiṇa universitātes Ētikas komitejas lēmumu 2010. gada 23. septembrī.

\section{Darba zinātniskā vadītāja:}

Dr. habil. med. profesore Ingrīda Čēma,

Rīgas Stradiṇa universitāte (Latvija)

\section{Oficiālie recenzenti:}

Dr. habil. med. profesors Andrejs Skaǵers,

Rīgas Stradiņa universitāte (Latvija)

Dr. med. asociētais profesors Jānis Eglītis,

Rīgas Austrumu klīniskā universitātes slimnīca (RAKUS),

Latvijas Onkologijas centrs (Latvija)

Dr. med. profesore Skaidra Valiukeviciene,

Lietuvas Veselības zinātṇu universitāte, Kauṇa (Lietuva)

Promocijas darba aizstāvēšana notiks 2014. gada 02. decembrī plkst. 15.00 Rīgas Stradiṇa universitātes Medicīnas promocijas padomes atklātā sēdē Rīgā, Dzirciema ielā 16, Senāta zālē.

Ar promocijas darbu var iepazīties RSU bibliotēkā un RSU mājas lapā: www.rsu.lv

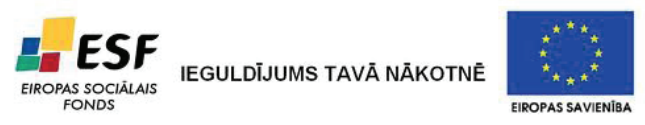

Promocijas darbs izstrādāts ar Eiropas sociālā fonda projekta "Atbalsts doktorantiem studiju programmas apguvei un zinātniskā grāda ieguvei Rīgas Stradiña universitātē" atbalstu, vienošanās Nr. 2009/0147/1DP/ 1.1.2.1.2/09/IPIA/VIAA/009.

Promocijas padomes sekretārs:

Dr. med. Arvīds Irmejs 


\section{SATURS}

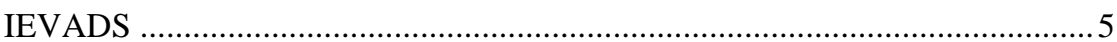

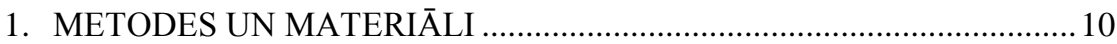

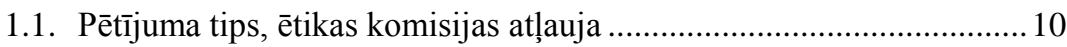

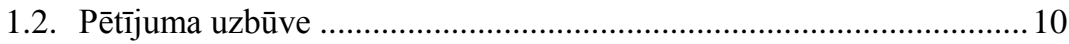

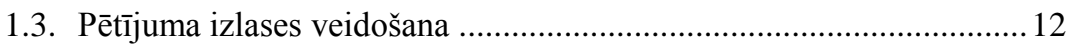

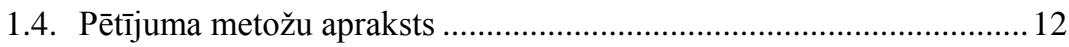

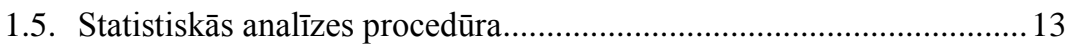

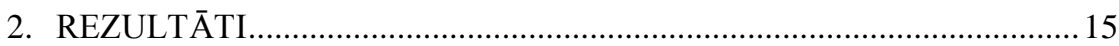

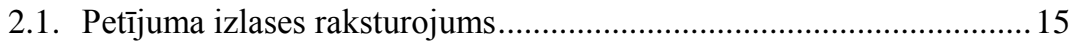

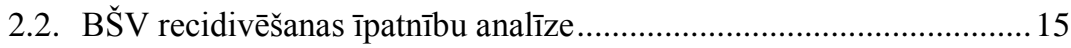

2.3. Dažādu sejas, galvas un kakla BŠV ārstēšanas metožu

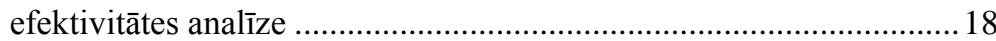

2.3.1. BŠV recidīvu biežuma likumsakarību noteikšana atkarībā no dažādām ārstēšanas metodēm un saistībā ar audzēja dažādiem faktoriem. 18

2.3.2. BŠV recidīvu biežuma salīdzinošā analīze dažādu ārstēšanas metožu gadījumā saistībā ar audzēja klīniski morfologisko formu, izmēru un precīzu audzēja anatomisko lokalizāciju 20

2.3.3. Prognostiskās BŠV recidīvu biežuma īpašības saistībā ar dažādām ārstēšanas metodēm, audzēja klīniski morfologisko formu, izmēru, precīzi norādītu anatomisko lokalizāciju un pacientu demogrāfiskajiem datiem.....

2.3.4. Dažādu BŠV ārstēšanas metožu kopsavilkuma analīze. 
2.4. Dažādu ārstēšanas metožu efektivitātes salīdzinošā analīze saistībā ar ādas kosmētiskā defekta (rētas) izteiktības pakāpi

3. DISKUSIJA

3.1. Sejas, galva un kakla BŠV klīniskās ainas un recidivēšanas īpatnību analīze 26

3.2. Sejas, galvas un kakla BŠV ārstēšanas metodes 29

3.3. Sejas, galvas un kakla BŠV ķirurğiskas ārstēšanas iespējas 30

3.4. Staru terapijas iespējas sejas, galvas un kakla BŠV ārstēšanā............ 32

3.5. Lāzerḳirurgiijas iespējas sejas, galvas un kakla BŠV ārstēšanā .......... 34

3.6. Kriodestrukcijas iespējas sejas, galvas un kakla BŠV ārstēšanā ........ 36

3.7. Ādas kosmētiskā defekta (rētas) izteiktības pakāpe ............................ 38

3.8. Iespējamā rezultātu ekstrapolācija citām ārstēšanas metodēm BŠV ārstěšanai 40

3.9. Attīstības perspektīvas un tālāko pētījumu iespējas 41

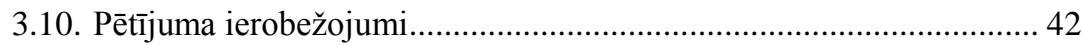

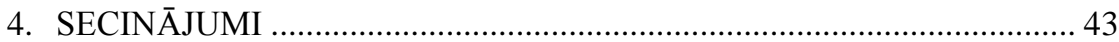

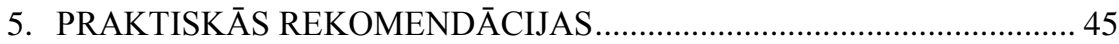

6. PUBLIKĀCIJAS UN ZIN̦OJUMI PAR PĒTĪJUMA TĒMU ..................... 46

Publikācijas (zinātniskie raksti) par pētījuma tēmu ...................................... 46

Konferenču tēzes par pētījuma tēmu ............................................................ 47

Ziṇojumi kongresos un konferencēs ............................................................. 48

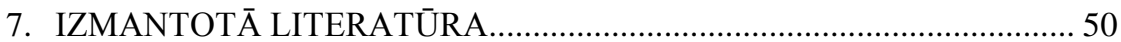

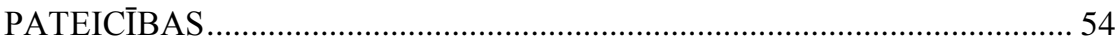




\section{IEVADS}

Ādas vēzis ir viena no biežāk sastopamajām vēža formām [1-5] .

Bazālo šūnu vēzis (BŠV) ir visbiežāk sastopamais l̦aundabīgais ādas audzējs kā Latvijā, tā arī pasaulē [6, 7]. BŠV ir lēni augošs, lokāli invazīivs ļaundabīgs epidermāls ādas audzējs, kas reti metastāzē [7, 8]. Mirstîbu izraisa plaši sejas, galvas vai kakla audu bojājumi, skarot dzīvībai svarīgos asinsvadus un orgānus $[9,10]$.

Pēdējos gados vērojams saslimstîbas pieaugums ar BŠV - ādas vēža pacientu vidū šĩ audzēja īpatsvars ir sasniedzis $5-10 \%$ [7]. Līdz šim BŠV vienmēr uzskatīja par vecāka gadagājuma cilvēku slimību, tomēr pēdējā laikā ir ievērojami pieaudzis darbspējas vecumā esošo pacientu skaits, kuriem ir svarīga ne tikai audzēja izārstēšana, bet arī kosmētiskais rezultāts, kas var ietekmēt pacientu sociālo rehabilitāciju [4, 11-13].

BŠV galvenās īpatnības ir bieži recidīvi, ilgstoša attīstība, lokalizācija tādās kosmētiski nozīmīgās vietās kā piere, vaigi, deguns, lūpas, acs plakstini, auss, galvas matainā daļa un kakls. Minētās lokalizācijas ir sastopamas 8090\% gadījumu [7, 14]. Vairākkārtīgi recidīvi ir viena no galvenajām problēmām BŠV pacientu ārstēšanā. Lielākoties recidīvi veidojas 0,5-3 gadus pēc pabeigtas ārstēšanas $[15,16]$. Tomēr dažos gadījumos recidīvi ir novēroti arī pēc 5-10 gadiem [3, 17, 18]. Primāro audzēju recidīvu biežums ir atkarīgs no ārstēšanas veida un ir sastopams $1-28 \%$ gadījumu, atkārtota recidivēšana iepriekšějā recidīva vietā - 4,8-42,8\% gadījumu [2, 3, 9, 17-24]. Problēmas būtība ârstēšanas metodes izvēlē ir tā, ka neviena no ārstēšanas metodēm nespēj nodrošināt 100\% izārstēšanu. Pēc dažādu autoru datiem, dažādu ārstēšanas veidu gadījumos recidīvu biežums ir atšķiīịs [25-30].

Pēdējo desmit gadu laikā ar ādas vēzi slimajiem pacientiem ḷoti svarīgs ir arī dzīves kvalitātes jautājums. Ir pierādīts, ka visi sejas ādas BŠV neatkarīgi 
no klīniskās formas var izraisīt dažādu pakāpju ādas kosmētisku defektu. Šie vizuālie defēkti ietekmē slimnieku dzīves kvalitāti, būtiski iespaido viṇu psihisko stāvokli un var izraisīt psihopatoloǵiskas reakcijas [31]. Psihiski robežstāvoklii ir konstatēti $82 \%$ bazālo šūnu ādas vēža pacientu [32]. Psihiskā stāvokḷa izmaiņas būtiski ietekmē l̦aundabīgā audzēja ārstēšanas procesa norisi, sociālo rehabilitāciju, nodarbinātību un dzīves kvalitāti kopumā [31-33].

Tādējādi biežā saslimstība, biežie recidīvi un lokalizācija sejas, galvas vai kakla ādā, kā arī kosmētiskie defekti, kas pasliktina pacienta dz̄̄ves kvalitāti un var izraisīt psihiskā stāvokḷa izmaiņas, rada nepieciešamību izvēlēties efektīvāku un arī kosmētiski piemērotāku ārstēšanas metodi [3, 34-36].

Aktuāls un sarežg̣īts ir jautājums par optimālās metodes izvēli apmierinoša kosmētiskā rezultāta ieguves nolūkā, ņemot vērā nepieciešamību radikāli atbrīvoties no jaunveidojumiem un panākt noturīgu klīnisko efektu.

\section{Promocijas darba mērķis}

Noteikt sejas, galvas un kakla bazālo šūnu vēža dažādu ārstēšanas metožu efektivitāti atbilstoši audzēja klīniski morfologiskajām formām, izmēriem un precīzi norādītām anatomiskajām lokalizācijām, ka ari salīdzināt sejas, galvas un kakla bazālo šūnu vēža dažādu ārstēšanas metožu efektivitāti atbilstoši ādas kosmētiskā defekta (rētas) izteiktības pakāpei.

\section{Promocijas darba uzdevumi}

Uzdevumu veikšana balstās uz vairāk nekā 5 gadu novērojumu datiem.

1. Analizēt bazālo šūnu vēža klīniskās ainas un recidivēšanas īpatn̄̄bas.

2. Salīdzināt četru ārstēšanas metožu (operāciju, staru terapiju, lāzerḳirurğiju un kriodestrukciju) efektivitāti atkarībā no recidīva veidošanās.

3. Analizēt recidīvu veidošanos pēc operācijas, staru terapijas, lāzerķirurǵijas un kriodestrukcijas atbilstoši primārā l̦aundabīgā 
audzēja klīniski morfologiskajai formai, izmēram, precīzi norādītai anatomiskajai lokalizācijai.

4. Noteikt operācijas, staru terapijas, lāzerķirurğijas un kriodestrukcijas izmantošanu ierobežojošos faktorus.

5. Novērtēt un salīdzināt dažādu ārstēšanas metožu efektivitāti vairāk nekā 5 gadus ilgas bezrecidīva gaitas gadījumos, ņemot vērā ādas kosmētiskā defekta (rētas) izteiktības pakāpi.

6. Izstrādāt rekomendācijas bazālo šūnu vēža optimālas ārstēšanas metodes izvēlei atbilstoši audzēja klīniski morfologiskajām formām, izmēriem, precīzi norādītām anatomiskajām lokalizācijām, pacienta vecumam, dzimumam un ādas kosmētiskā defekta (rētas) izteiktības pakāpei.

\section{Promocijas darba zinātniskā novitāte}

Pirmo reizi veikta:

1. Kompleksa sejas, galvas un kakla bazālo šūnu vēža ārstēšanas metožu efektivitātes salīdzinošā analīze pēc vairāk nekā 5 gadus ilgas novērošanas.

2. Kompleksa salīdzinošā dažādu bazālo šūnu vēža klīniski morfologisko formu ar precīzi norādītu anatomisko lokalizāciju un izmēru ārstēšanas metožu analīze.

3. Ādas kosmētiskā defekta (rētas) izteiktības pakāpes nozīmes salīdzinošā analīze pēc sejas, galvas un kakla bazālo šūnu vēža ārstēšanas vairāk nekā 5 gadu ilgā bezrecidīva novērošanas periodā.

\section{Promocijas darba praktiskā novitāte}

Pētījumā iegūtie rezultāti dod iespēju izstrādāt ārstēšanas algoritmu atbilstoši audzēja klīniski morfolog̣iskajām formām, izmēram un precīzi norādītai anatomiskajai lokalizācijai. Izstrādāto ārstēšanas algoritmu un 
unificēto ādas vēža slimnieka klīnisko karti var rekomendēt lietošanai dermatologu, ķirurgu un onkologu ambulatorajā praksē.

\section{Aizstāvēšanai izvirzītā hipotēze}

Noteiktu sejas, galvas un kakla bazālo šūnu vēža klīniski morfoloǵisko formu, izmēra un precīzi norādītas lokalizācijas gadījumā tādas alternatīvas ārstēšanas metodes kā staru terapija, lāzerķirurǵija, kriodestrukcija ir tikpat efektīvas kā tradicionālā ārstēšanas metode - operācija. Turklāt alternatīvās ārstēšanas metodes dod iespēju iegūt mazāk izteiktu ādas kosmētisko defektu (rētu).

\section{Promocijas darba veikšanas laiks un vieta}

Promocijas darbs veikts laikā no 2010. gada novembra līdz 2013. gada septembrim. Darbs izstrādāts SIA "Rīgas Austrumu klīniskā universitātes slimnīca” Latvijas Onkologijas centrā.

\section{Personīgais ieguldījums}

Literatūras avotu un pasaules pētījumu rezultātu analīze, pētîjuma dizaina izstrādāšana un saskaņošana RSU Ėtikas komitejā, pacientu medicīnas dokumentācijas atlase, medicīnas datu sistematizācija saskaņā ar izvēlētajiem indikatoriem, pacienta kārtējā veselības stāvokḷa kontrole, iegūto rezultātu analīze, promocijas darba materiālu apkopojums, praktisko rekomendāciju izstrāde, publikāciju, tēžu un promocijas darba rakstīšana.

\section{Promocijas darba apjoms un struktūra}

Promocijas darbs uzrakstīts latviešu valodā. Promocijas darba sadaḷas: ievads, literatūras apskats, materiāli un metodes, rezultāti, diskusija, secinājumi un izmantotās literatūras saraksts. Darba apjoms ir 138 lappuses. Darbā ir 39 tabulas, 13 attēli un 5 pielikumi. Vērēs iekḷauti 235 nosaukumi. 


\section{Ētikas komitejas ațauja}

Pētījums ir apstiprināts Rīgas Stradiņa universitātes Ētikas komitejā 2010. gada 23. septembrī (1. pielikums). 


\section{METODES UN MATERIĀLI}

\subsection{Pētijuma tips, ètikas komisijas aț̦auja}

Pētījuma tips - retrospektīvs. Pētījums ir apstiprināts ar Rīgas Stradiña universitātes Ētikas komitejas lēmumu 2010. gada 23. septembrī (1. pielikums)

\subsection{Pētījuma uzbūve}

Pētījumam ir divas daļas: 1. daḷa - sejas, galvas un kakla bazālo šūnu vēža dažādu ārstēšanas metožu efektivitātes analīze, ņemot vērā recidīva veidošanos (novērošana ilgst vairāk nekā 5 gadus pēc ārstēšanas) (turpmāk darbā "recidīvu analīze"); 2. daḷa - sejas, galvas un kakla bazālo šūnu vēža dažādu ārstēšanas metožu efektivitātes analīze, ņemot vērā ādas kosmētiskā defekta (rētas) izteiktības pakāpi (turpmāk - "rētas analīze"), ja vairāk nekā 5 gadu novērošanas periodā pacientam netika konstatēts sejas, galvas un kakla BŠV recidīvs.

Pètījuma 1. posms: pētījuma izlases veidošana: medicīniskās dokumentācijas atlase pēc noteiktiem kritērijiem laika periodā no 01.01.2000. gada līdz 31.12.2005. gadam.

Pètījuma 2. posms: darbs ar pētījumam atlasīto medicīnisko dokumentāciju: medicīnas datu sistematizācija, saskaņā ar izvirzītajiem indikatoriem.

Pètījuma 3. posms: recidīvu analīze - salīdzinošā analīze un dažādu ārstēšanas metožu efektivitātes konstatēšana, pamatojoties uz audzēja klīniskimorfologiskām formām, precīzi norādītu lokalizāciju un izmēru

Pētījuma 4. posms: dažādu ārstēšanas metožu efektivitātes salīdzinošā analīze, ņemot vērā ādas kosmētiskā defekta (rētas) izteiktības pakāpes. Šim posmam ir vairāki apakšposmi: 1) gadījumu atlase, ja vairāk nekā 5 gadu novērošanas periodā netika konstatēts BŠV recidīvs; 2) tikšanās ar pacientu, 
informētas piekrišanas noformēšana, pacienta kārtējā veselības stāvokḷa kontroles veikšana, anketēšana un rētas fotografěšana; 3) ādas kosmētiskā defekta (rētas) izteiktības pakāpe neatkarīgu ekspertu vērtējumā; 4) iegūto datu salīdzinošā analīze.

Pètījuma 5. posms: BŠV ārstēšanas algoritma izveide.

1.1 attēlā redzama pētījuma uzbūve, kurā ir pieci savstarpēji saistîti posmi.

\section{I posms}

Pētījuma izlases veidošana $(\mathrm{n}=2550)$

Darbs ar medicīnisko dokumentāciju

\section{II posms}

Medicīnisko datu sistematizācija atbilstoši izvirzītajiem indikatoriem

\begin{tabular}{|l|}
\multicolumn{1}{|c|}{$\underline{\underline{\text { III posms }}}$} \\
Recidīvu analīze $(\mathrm{n}=968)$ \\
$\begin{array}{l}\text { Dažādu ārstēšanas metožu efektivitātes } \\
\text { noteikšana, ņemot vērā audzēja KMF, } \\
\text { lokalizāciju, izmēru }\end{array}$ \\
\hline Aprakstošās statistikas metodes \\
Secinošās statistikas metodes \\
Pearson $\chi^{2}$ \\
Fisher's exact test \\
Spearman rank korelācijas \\
koeficients \\
Kaplan-Meyer metode \\
Loğistiskā regresija \\
ROC līknes analīze
\end{tabular}

\section{IV posms}

Rētas analīze $(\mathrm{n}=842)$

Dažādu ārstēšanas metožu efektivitātes noteikšana, ņemot vērā ādas kosmētiskā defekta (rētas) izteiktības pakāpi $(\mathrm{n}=195)$

Aprakstošās statistikas metodes

Secinošās statistikas metodes

Kruskal-Wallis H-tests

Mann-Whitney U-tests ar Bonferoni labojumu

Interclass Correlation Coeficient

\section{$\mathrm{V}$ posms}

Bazālo šūnu vēža ărstēšanas algoritma izveide Ārstēšanas kalkulatora izveide

1.1. att. Pētījuma uzbūve 


\subsection{Pētījuma izlases veidošana}

Pētijumā bija atlasīti pacienti, kas ārstēti LOC no 01.01.2000. gada līdz 31.12.2005. gadam [6]. Pacientu atlase izmantoti medicīniskās dokumentācijas dati (ambulatorā pacienta medicīniskā karte - veidlapa Nr. 025/u).

Kritēriji pacientu iekļaušanai pētījumā: 1) morfologiski (histoloǵiski vai citologiski) apstiprināta diagnoze - primārs BŠV ar T1-T2N0M0 (saskaņā ar UICC 2009 TNM klasifikāciju, 7. redakciju); 2) vecums sākot ar 18 gadiem; 3) BŠV lokalizācija sejas, galvas vai kakla zonā ar Starptautiskās statistiskās slimības un veselības problēmu klasifikācijas kodiem C44.0 - lūpas āda, C44.1 - acs plakstiņa āda, C44.2 - auss un ārējās auss ejas āda, C44.3 - citi l̦aundabīgi ādas audzēji, citu un neprecizētu sejas daļu āda, C44.4 - galvas matainās daļas un kakla āda (SSK-10. redakcijā); 4) pacienti ir dzīvi un konsultējas LOC vairāk nekā 5 gadus no ārstēšanas sākuma; 5) ārstiem, kas veica ārstēšanu, darba stāžs onkoloǵijā ir ne mazāk kā 10 gadi.

Kritēriji pacientu izslēgšanai no pētījuma: 1) pacienti, kuri saņēmuši kombinētu terapiju; 2) pacienti, kuri atteikušies no ārstēšanas; 3) pacienti, kuri nav ieradušies uz kontroli vairāk nekā 5 gadus; 4) pacienti, kuru ambulatorās medicīniskās kartes netika atrastas.

Pētījumā pirma dạ̦ā iekḷauta medicīniskā dokumentācija par 968 pacientiem. Turpmākajā medicīniskās dokumentācijas apstrādes posmā visi pacienti sadalīti četrās grupās atbilstoši ārstēšanas veidam. Otrās pētījuma daļa pētnieciskā izlase veidota no tiem pacientiem, kuriem vairāk nekā 5 gadus ilgās novērošanas laikā netika konstatēts recidīvs, un tāja iekḷauti 842 pacienti. Ekspertu vērtējumam tika iekḷautas 195 pacientu fotogrāfijas.

\subsection{Pētījuma metožu apraksts}

Pirmās pētījuma kārtas veikšanai, bija nepieciešama medicīnas datu sistematizācija un turpmāka statistiskā apstrāde, tādēḷ autors izstrādāja 
“paz̄imju klasifikatoru”. Šajā klasifikatorā tika iekḷauta sekojoša informācija: 1) pacienta identifikācijas dati (medicīnas kartinas šifrs), 2) pacienta demogrāfiskie dati (vecums, dzimums), 3) audzēja lokalizācija saskaņā ar UICC 2009 TNM klasifikāciju, 4) precīzi norādīta anatomiskā lokalizācija (lūpa, acs plakstiņš, auss, deguns, piere, vaigs, zods, galvas matainā daļa, kakls; 5) audzēja izmērs milimetros $(\mathrm{mm})$ - saskaņā ar NCCN rekomendācijām iedalīt sejas, galvas un kakla ādu $\mathrm{H}$ un $\mathrm{M}$ zonās, tika izveidotas un analizētas 4 pētījuma grupas, kur pacientiem audzēja izmērs bija $<6 \mathrm{~mm}, 6-10 \mathrm{~mm}$, 11-20 mm un > $20 \mathrm{~mm}$ [7]; 6) BŠV klīniskā forma (virspusējs, nodulārs, infiltratīvs audzējs) un audzēja histologiskais variants; 7) ārstēšanas datums, 8) izvēlētais ārstēšanas veids, 9) recidīva esamība; datums, kad primārs recidīvs tika konstatēts; 10) pacienta novērošanas ilgums.

Pētījuma otraja dạ̄ā tika novērtēta ādas kosmētiskā defekta (rētas) izteiktības pakāpe - to veica neatkarīgi eksperti pēc vizuālo analogu skalas (Visual Analoge Scale (VAS)) [37].

\subsection{Statistiskās analīzes procedūra}

1.posms: dažādu BŠV ārstēšanas metožu efetivitātes salīdzinoša à analīze.

Recidīva biežuma salīdzinošā analīze veikta, ņemot vērā audzēja klīniski morfologiisko formu, precīzi norādīto anatomisko lokalizāciju, izmēru, pacienta vecumu un dzimumu. Sākotnējai datu raksturošanai izmantota aprakstošāa statistika, turpinājumā veikta datu statistiskā apstrāde, ticamas atšķirības noteikšanai starp recidīva biežumu operācijas un citu ārstēšanas metožu lietošanas gadījumā. Laiks līdz recidīvam, kopējais novērošanas ilgums analizēts izmantojot Kaplan-Meier metodi. Neparametrisko datu analīzei lietots Pearson $\chi^{2}$ un Fisher's Exact test (ja kādā no kontingences tabulas šūnām ir mazs $(\mathrm{n}<5)$ sagaidāmo objektu skaits) [38]. Tika noteikts, ka rezultāti ir statistiski ticami, ja $p<0,05$. Lai noteiktu saistību starp ārstēšanas rezultātu un 
audzēju raksturojošiem faktoriem, kā arī demogrāfiskajiem datiem lietota daudzfaktoru binārās logistiskās regresijas metode un ROC (Receiver Operating Charateristic) līknes analīze. Recidīvu biežuma un BŠV izmēru, kā arī pacienta demogrāfisko datu (vecuma, dzimuma) savstarpējās korelācijas novērtēšanai izmantots Spearman's rank korelācijas koeficients.

2. posms: sejas, galvas un kakla bazālo šūnu vēža dažādu ārstēšanas metožu efektivitātes salīdzinošā analīze, ņemot vērā ādas kosmētiskā defekta (rētas) izteiktības pakāpi veikta, pamatojoties uz ekspertu sniegto vērtējumu. Iegūto vērtējumu vispārējai raksturošanai lietotas aprakstošās statistikas metodes. Pirms secinošās statistikas instrumentu lietošanas bija jāpārbauda ekspertu vērtējumu vienprātība (konsensuss). Ekspertu novērtējumu vienprātības noteikšanai katras grupas ietvaros tika izmantots Intraclass Correlation Coefficient (ICC). Darba turpinājumā dati analizēti, izmantojot Kruskal-Wallis H-testa kritēriju, lai noskaidrotu atšķirību statistisko ticamību ādas kosmētiskā defekta (rētas) izteiktības pakāpes vērtējumos, salīdzinot dažādas ārstēšanas. Atšķirību starp ārstēšanas metodēm statistiskās ticamības noteikšanai tika lietots Mann-Whitney U-tests ar Bonferroni adjustment būtiskuma līmeņa $p$ vērtībai, kas l̦āva veikt grupu salīdzināšanu pa pāriem [38].

Datu statistiskajai analīzei izmantota programma IBM SPSS 20.0 versija. 


\section{REZULTĀTI}

\subsection{Petījuma izlases raksturojums}

Pētījumā izmantoti dati no ambulatoro pacientu kartēm par 968 pacientiem - 634 sievietēm $(65,5 \%)$ un 334 vīriešiem (34,5\%). Dati par pacientiem, kam nozīmēts kāds no četriem ārstēšanas veidiem, analizēti atsevišķi 2.1. tabulā.

2.1. tabula

Pētījuma izlases pacientu demogrāfiskie rādītāji

\begin{tabular}{|l|c|c|c|c|c|c|c|c|}
\hline & $\begin{array}{c}\text { Pacienti, } \\
\mathrm{n}\end{array}$ & $\begin{array}{c}\text { Vīrieši, } \\
\mathrm{n}(\%)\end{array}$ & $\begin{array}{c}\text { Sievietes, } \\
\mathrm{n}(\%)\end{array}$ & $\begin{array}{c}\text { Vidējais } \\
\text { vecums, } \\
\mathrm{M}\end{array}$ & $\begin{array}{c}\text { Standart- } \\
\text { novirze } \\
\text { SD }\end{array}$ & Min & Max & $\begin{array}{c}\text { Vecuma } \\
\text { moda }\end{array}$ \\
\hline Operācija & 273 & $\begin{array}{c}107 \\
(39,2 \%)\end{array}$ & $\begin{array}{c}166 \\
(60,8 \%)\end{array}$ & 62,14 & 13,61 & 20 & 87 & 60 \\
\hline $\begin{array}{l}\text { Staru } \\
\text { terapija }\end{array}$ & 223 & $\begin{array}{c}109 \\
(48,9 \%)\end{array}$ & $\begin{array}{c}114 \\
(51,1 \%)\end{array}$ & 69,33 & 12,02 & 28 & 87 & 77 \\
\hline $\begin{array}{l}\text { Lāzer- } \\
\text { ķirurğija }\end{array}$ & 341 & $\begin{array}{c}66 \\
(19,4 \%)\end{array}$ & $\begin{array}{c}275 \\
(80,6 \%)\end{array}$ & 63,74 & 12,97 & 26 & 92 & 75 \\
\hline $\begin{array}{l}\text { Krio- } \\
\text { destrukcija }\end{array}$ & 131 & $\begin{array}{c}52 \\
(39,7 \%)\end{array}$ & $\begin{array}{c}79 \\
(60,3 \%)\end{array}$ & 67,58 & 7,94 & 42 & 86 & 70 \\
\hline \multicolumn{1}{|c|}{ Kopā } & 968 & $\begin{array}{c}334 \\
(34,5 \%)\end{array}$ & $\begin{array}{c}634 \\
(65,5 \%)\end{array}$ & 65,10 & 12,68 & 20 & 92 & 70 \\
\hline
\end{tabular}

\subsection{BŠV recidivēšanas īpatnību analīze}

BŠV recidivēšanas īpatnības ir redzamas 2.2., 2.3., 2.4. tabulās un 2.1., 2.2. attēlos.

Recidīvu sadalījums pēc klīniski morfologiskās formas

\begin{tabular}{|l|c|c|c|}
\hline Klīniski morfoloğiskā forma & $\mathrm{n}$ & $\mathrm{R}$ & $\mathrm{R}, \%$ \\
\hline Virspusēja & 388 & 42 & 10,82 \\
\hline Nodulāra & 536 & 57 & 10,64 \\
\hline Infiltratīva & 44 & 27 & 61,36 \\
\hline Kopā & 968 & 126 & 13,02 \\
\hline
\end{tabular}

$\mathrm{n}$ - kopējais gadījumu skaits grupā; $\mathrm{R}$ - recidīvu skaits; $\mathrm{R}, \%$ - recidīvu biežums 
BŠV recidīvu biežuma sadalījums pēc audzēju izmēra

\begin{tabular}{|c|c|c|c|}
\hline Audzēja izmērs, mm & $\mathrm{n}$ & $\mathrm{R}$ & $\mathrm{R}, \%$ \\
\hline$<6 \mathrm{~mm}$ & 184 & 11 & 5,98 \\
\hline $6-10 \mathrm{~mm}$ & 626 & 84 & 13,42 \\
\hline $11-20 \mathrm{~mm}$ & 117 & 24 & 20,51 \\
\hline$>20 \mathrm{~mm}$ & 41 & 7 & 17,07 \\
\hline
\end{tabular}

$\mathrm{n}$ - kopējais gadījumu skaits grupā; $\mathrm{R}$ - recidīvu skaits; R, \% - recidīvu biežums

Veicot korelācijas analīzi, bija secināts, ka pastāv statistiski ticama pozitīva korelācija starp audzēja izmēru un recidīva biežumu - Spearman's rank korelācijas koeficients $p=0,01$.

Recidīvu biežums saistībā ar precīzu audzēja anatomisko lokalizāciju, ir redzams 2.1. attelā.

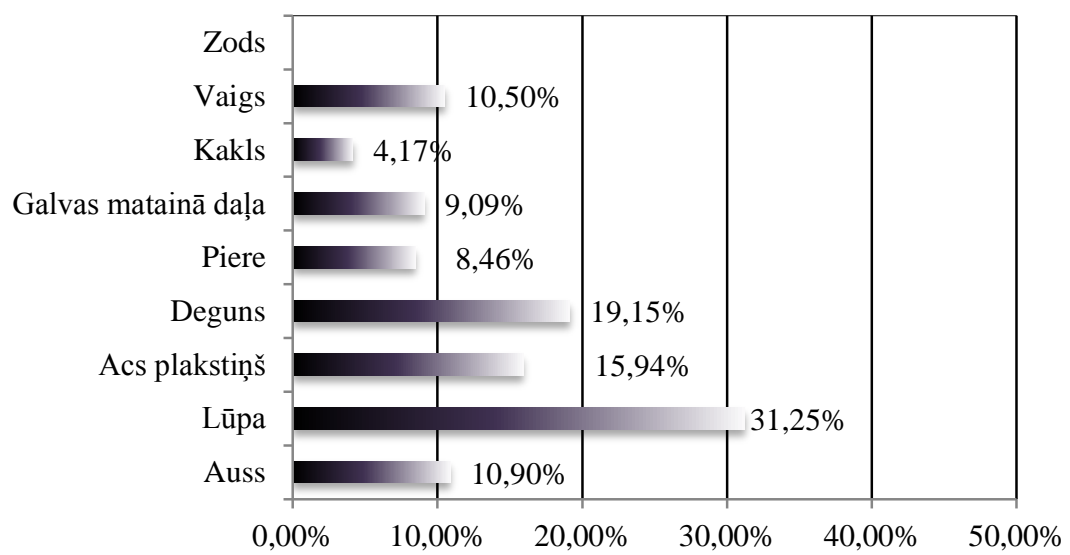

2.1. att. BŠV recidīvu biežuma sadalījums (\%) pēc precīzi norādītas audzēja anatomiskās lokalizācijas

Netika konstatētas atšķirības recidīvu biežumā saistībā ar dzimumu: sievietēm recidīvi veidojās $13,41 \%$ gadījumu, vīriešiem - 12,27\%. Veicot Spearman's rank analīzi, secināts, ka nav konstatējama statistiski ticama korelācija starp pacientu dzimumu un recidīvu biežumu. 
BŠV recidīvu biežuma sadalījums (\%) pēc pacientu vecuma ir redzams 2.2. attēlā.

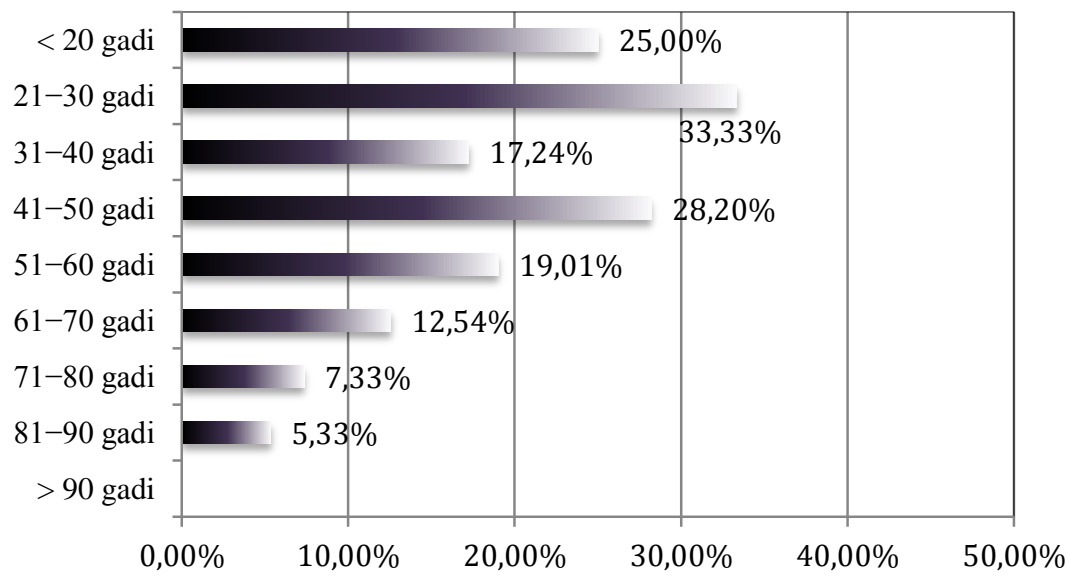

\section{2. att. BŠV recidīvu biežuma sadalījums (\%) pēc pacientu vecuma}

Veicot korelācijas analīzi, secināts, ka pastāv statistiski ticama negatīva korelācija starp vecumu un recidīvu biežumu - Spearman's rank korelācijas koeficients $p=0,01$.

Izmantojot Kaplan-Meyer metodi, secināts, ka kopējā recidīvu parādīšanās laika mediāna ir 22,0 mēneši (2.4. tabula).

2.4. tabula

\section{Laiks (mēneši) līdz BŠV recidivēšanai: vidējais aritmētiskais un mediāna}

\begin{tabular}{|c|c|c|c|c|c|c|c|c|}
\hline \multirow{3}{*}{$\begin{array}{l}\text { Ārstēšanas } \\
\text { veids }\end{array}$} & \multicolumn{4}{|c|}{$\begin{array}{l}\text { Vidējais aritmētiskais laiks } \\
\text { lìdz recidivēšanai }(M) \text {, mēneši }\end{array}$} & \multicolumn{4}{|c|}{$\begin{array}{l}\text { Laika līdz recidivēšanai mediāna, } \\
\text { mēneši }\end{array}$} \\
\hline & \multirow{2}{*}{$\begin{array}{l}\text { aprēķi- } \\
\text { nātais }\end{array}$} & \multirow{2}{*}{$\begin{array}{l}\text { standart- } \\
\text { kḷūda }\end{array}$} & \multicolumn{2}{|c|}{$\begin{array}{c}\text { 95\% Ticamības } \\
\text { intervāls (TI) }\end{array}$} & \multirow{2}{*}{$\begin{array}{l}\text { aprēksi- } \\
\text { nātais }\end{array}$} & \multirow{2}{*}{$\begin{array}{l}\text { standart- } \\
\text { kḷūida }\end{array}$} & \multicolumn{2}{|c|}{$\begin{array}{l}\text { 95\% Ticamības } \\
\text { intervāls (TI) }\end{array}$} \\
\hline & & & $\begin{array}{l}\text { apakšējā } \\
\text { robeža }\end{array}$ & $\begin{array}{l}\text { augšējā } \\
\text { robeža }\end{array}$ & & & $\begin{array}{c}\text { apakšejēā } \\
\text { robeža }\end{array}$ & $\begin{array}{l}\text { augšèjā } \\
\text { robeža }\end{array}$ \\
\hline Operācija & 36,0 & 5,9 & 24,4 & 47,6 & 24,0 & 8,4 & 7,5 & 40,5 \\
\hline Staru terapija & 42,1 & 7,1 & 28,2 & 55,9 & 36,0 & 4,2 & 27,8 & 44,2 \\
\hline Lāzerḳirurğija & 22,4 & 2,3 & 18, & 26,8 & 19,0 & 2,7 & 13,6 & 24,4 \\
\hline Kriodestrukcija & 30,0 & 4,7 & 20,8 & 39,1 & 20,0 & 3,5 & 13,0 & 26,9 \\
\hline Kopā & 30,2 & 2,3 & 25,7 & 34,7 & 22,0 & 1,8 & 18,5 & 25,5 \\
\hline
\end{tabular}




\subsection{Dažādu sejas, galvas un kakla BŠV ārstēšanas metožu efektivitātes analīze}

Par galveno BŠV ārstēšanas efektivitātes kritēriju uzskata recidīva trūkumu [3, 7]. Tādēḷ ir jāsalīdzina recidīvu biežumu pēc operācijas ar situāciju pēc pārējām BŠV ārstēšanas metodēm (staru terapijas, lāzerķirurğijas un kriodestrukcijas). Bez tam recidīvu veicinošo faktoru noteikšanai ir jāņem vērā ne tikai ārstēšanas metode, bet arī audzēja klīniski morfoloǵiskā forma, izmērs un precīzi norādīta anatomiskā lokalizācija.

\subsubsection{BŠV recidīvu biežuma likumsakarību noteikšana atkarībā no dažādām ārstēšanas metodēm un saistībā ar audzēja dažādiem faktoriem}

Recidīva biežumu aprakstošās statistikas rezultāti saistībā ar ārstēšanas metodēm ir redzami 2.5., 2.6., 2.7., 2.8. tabulās un 2.3. attelā.

2.5. tabula

BŠV recidīvu biežuma sadalījums pēc saṇemtās ārstēěanas metodes

\begin{tabular}{|l|c|c|c|}
\hline \multicolumn{1}{|c|}{ Ārstēšanas metode } & $\mathrm{n}$ & $\mathrm{R}$ & $\mathrm{R}, \%$ \\
\hline Operācija & 273 & 25 & 9,2 \\
\hline Staru terapija & 223 & 19 & 8,5 \\
\hline Lāzerk̦irurğija & 341 & 47 & 13,8 \\
\hline Kriodestrukcija & 131 & 35 & 26,7 \\
\hline Kopā & 968 & 126 & 13,02 \\
\hline
\end{tabular}

$\mathrm{n}$ - kopējais gadījumu skaits grupā; $\mathrm{R}$ - recidīvu skaits; R, \% - recidīvu biežums

2.6. tabula

BŠV recidīvu biežuma sadalījums pēc audzēja klīniski morfoloğiskās formas un saṇemtās ārstēšanas metodes

\begin{tabular}{|c|c|c|c|c|c|c|c|c|c|c|c|c|}
\hline \multirow[t]{2}{*}{ BŠV } & \multicolumn{3}{|c|}{ Operācija } & \multicolumn{3}{|c|}{$\begin{array}{l}\text { Staru } \\
\text { terapija }\end{array}$} & \multicolumn{3}{|c|}{$\begin{array}{c}\text { Lāzerķirurǵi } \\
\text { ja }\end{array}$} & \multicolumn{3}{|c|}{$\begin{array}{c}\text { Kriodestruk- } \\
\text { cija }\end{array}$} \\
\hline & $\mathrm{n}$ & $\mathrm{R} \mid \mathrm{I}$ & $\mathrm{R}, \%$ & $\mathrm{n}$ & $\mathrm{R}$ & $\mathrm{R}, \%$ & $\mathrm{n}$ & $\mathrm{R}$ & $\mathrm{R}, \%$ & $\mathrm{n}$ & $\mathrm{R}$ & $\mathrm{R}, \%$ \\
\hline Virs & 70 & 4 & 5,7 & 100 & 5 & 5,0 & 137 & 14 & 10,2 & 81 & 19 & 23,5 \\
\hline Nodulāra KMF & 184 & 17 & 9,2 & 116 & 8 & 6,9 & 188 & 18 & 9,6 & 48 & 14 & 29,2 \\
\hline Infiltratīva KMF & 19 & 4 & 21,1 & 7 & 6 & 86,0 & 16 & 15 & 93,8 & 2 & 2 & 100, \\
\hline
\end{tabular}

$\mathrm{R}$ - recidīvu skaits; R, \% - recidīvu biežums ; KMF - klīniski morfoloǵiskā forma 
2.7. tabula

BŠV recidīvu biežuma sadalījums pēc audzēja izmēra un ārstēšanas metodes

\begin{tabular}{|c|c|c|c|c|c|c|c|c|c|c|c|c|}
\hline \multirow{2}{*}{$\begin{array}{l}\text { Audzēja } \\
\text { izmērs, } \\
\text { mm }\end{array}$} & \multicolumn{3}{|c|}{ Operācija } & \multicolumn{3}{|c|}{ Staru terapija } & \multicolumn{3}{|c|}{ Lāzerksirurǵija } & \multicolumn{3}{|c|}{ Kriodestrukcija } \\
\hline & $\mathrm{n}$ & $\mathrm{R}$ & $\mathrm{R}, \%$ & $\mathrm{n}$ & $\mathrm{R}$ & $\mathrm{R}, \%$ & $\mathrm{n}$ & $\mathrm{R}$ & $\mathrm{R}, \%$ & $\mathrm{n}$ & $\mathrm{R}$ & $\mathrm{R}, \%$ \\
\hline$<6 \mathrm{~mm}$ & 55 & 1 & 2,0 & 25 & 2 & 8,0 & 73 & 5 & 6 , & 31 & 3 & 9,7 \\
\hline 6-10mm & 159 & 13 & 8,2 & 145 & 9 & 6,2 & 232 & 34 & 14,7 & 90 & 28 & 31,1 \\
\hline $11-20 \mathrm{~mm}$ & 38 & 8 & 21,1 & 39 & 6 & 15,4 & 30 & 6 & 20,0 & 10 & 4 & 40,0 \\
\hline$>20 \mathrm{~mm}$ & 21 & 3 & 14,3 & 14 & 2 & 14,3 & 6 & 2 & 33,3 & - & - & - \\
\hline
\end{tabular}

$\mathrm{n}$ - kopējais gadījumu skaits grupā; $\mathrm{R}$ - recidīvu skaits; $\mathrm{R}, \%$ - recidīvu biežums

2.8. tabula

BŠV recidīvu biežuma sadalījums pēc audzēja anatomiskās lokalizācijas un ārstēšanas metodes

\begin{tabular}{|c|c|c|c|c|c|c|c|c|c|c|c|c|}
\hline \multirow{2}{*}{$\begin{array}{c}\text { Audzēja } \\
\text { anatomiskā } \\
\text { lokalizācija }\end{array}$} & \multicolumn{3}{|c|}{ Operācija } & \multicolumn{3}{c|}{ Staru terapija } & \multicolumn{2}{c|}{ Lāzerkirurǵija } & \multicolumn{3}{c|}{ Kriodestrukcija } \\
\cline { 2 - 16 } & $\mathrm{n}$ & $\mathrm{R}$ & $\mathrm{R}, \%$ & $\mathrm{n}$ & $\mathrm{R}$ & $\mathrm{R}, \%$ & $\mathrm{n}$ & $\mathrm{R}$ & $\mathrm{R}, \%$ & $\mathrm{n}$ & $\mathrm{R}$ & $\mathrm{R}, \%$ \\
\hline Auss & 28 & 1 & 3,6 & 14 & 1 & 7,0 & 8 & 2 & 25,0 & 5 & 2 & 40,0 \\
\hline Lūpa & 5 & 0 & 0 & 2 & 0 & 0 & 7 & 3 & 42,9 & 2 & 2 & 100,0 \\
\hline $\begin{array}{c}\text { Acs } \\
\text { plakstiňs }\end{array}$ & 31 & 5 & 16,1 & 17 & 3 & 18,0 & 19 & 3 & 15,8 & 2 & 0 & 0 \\
\hline Deguns & 68 & 8 & 12,0 & 60 & 9 & 15,0 & 129 & 22 & 17,1 & 51 & 20 & 39,2 \\
\hline Piere & 38 & 1 & 2,6 & 45 & 1 & 2,2 & 77 & 8 & 10,4 & 29 & 6 & 20,7 \\
\hline $\begin{array}{c}\text { Galvas ma- } \\
\text { tainā dal̦a }\end{array}$ & 30 & 4 & 13,3 & 38 & 2 & 5 & 10 & 0 & 0 & 10 & 2 & 20,0 \\
\hline Kakls & 17 & 1 & 6,0 & 4 & 0 & 0 & 14 & 1 & 7,1 & 13 & 0 & 0 \\
\hline Vaigs & 51 & 5 & 9,8 & 41 & 3 & 7,3 & 70 & 8 & 11,4 & 19 & 3 & 15,8 \\
\hline Zods & 5 & 0 & 0 & 2 & 0 & 0 & 7 & 0 & 0 & 5 & 0 & 0 \\
\hline
\end{tabular}

$\mathrm{n}$ - kopējais gadījumu skaits grupā; $\mathrm{R}$ - recidīvu skaits; $\mathrm{R}, \%$ - recidīvu biežums 


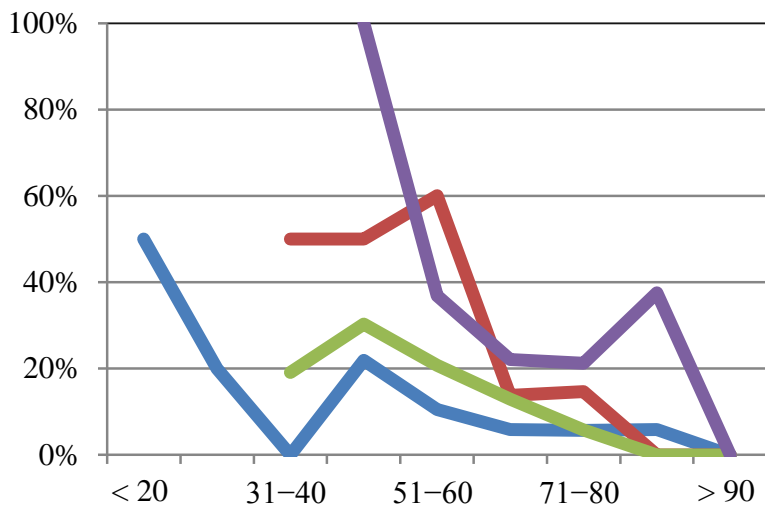

Operācija

Staru terapija

Lāzerķirurǵija

Kriodestrukcija

2.3. att. BŠV recidīvu biežuma sadalījums (\%) pēc pacienta vecuma un audzēja ārstēšanas metodes

\subsubsection{BŠV recidīvu biežuma salīdzinošā analīze dažādu ārstēšanas metožu gadījumā saistībā ar audzēja klīniski morfoloǵisko formu, izmēru un precīzu audzēja anatomisko lokalizāciju}

BŠV recidīvu biežuma salīdzinājums pēc klīniski morfologiskajām formām, izmēra un precīzas audzēju anatomiskās lokalizācijas ir redzams 2.9., 2.10. un 2.11. tabulas.

2.9. tabula

BŠV recidīvu biežuma salīdzinājums pēc audzēja klīniski morfoloğiskajām formām un to ārstēšanas metodēm

\begin{tabular}{|l|c|c|c|}
\hline \multicolumn{1}{|c|}{ BŠV klīniski } & Staru terapija, & Lāzerḳirurǵija, & Kriodestrukcija, \\
morfoloğiskās formas & $p$ & $p$ & $p$ \\
\hline Virspusēja & $1,000 \mathrm{~ns}$ & $0,227 \mathrm{~ns}$ & $0,002 * *$ \\
\hline Nodulāra & $0,475 \mathrm{~ns}$ & $0,912 \mathrm{~ns}$ & $<0,001 * * *$ \\
\hline Infiltratīva & $0,005 * *$ & $<0,001 * * *$ & $<0,001 * * *$ \\
\hline
\end{tabular}

$p-$ Pearson $\chi^{2}$ vai Fisher's exact test 
BŠV recidīvu biežuma salīdzinājums pēc audzēju izmēra un to ārstēšanas metodēm

\begin{tabular}{|c|c|c|c|}
\hline \multirow{2}{*}{ Audzēja izmērs } & $\begin{array}{c}\text { Staru terapija, } \\
p\end{array}$ & $\begin{array}{c}\text { Lāzerķirurǵija, } \\
p\end{array}$ & $\begin{array}{c}\text { Kriodestrukcija, } \\
p\end{array}$ \\
\hline$<6 \mathrm{~mm}$ & $0,229 \mathrm{~ns}$ & $0,236 \mathrm{~ns}$ & $0,131 \mathrm{~ns}$ \\
\hline $6-10 \mathrm{~mm}$ & $0,508 \mathrm{~ns}$ & 0,053 & $<0,001 * * *$ \\
\hline $11-20 \mathrm{~mm}$ & $0,519 \mathrm{~ns}$ & $0,915 \mathrm{~ns}$ & $<0,001 * * *$ \\
\hline$>20 \mathrm{~mm}$ & $1,000 \mathrm{~ns}$ & $0,303 \mathrm{~ns}$ & - \\
\hline
\end{tabular}

2.11. tabula

BŠV recidīvu biežuma salīdzinājums pēc precīzas audzēju anatomiskās lokalizācijas un to ārstēšanas metodēm

\begin{tabular}{|l|c|c|c|}
\hline $\begin{array}{l}\text { Audzēja } \\
\text { anatomiskā } \\
\text { lokalizācija }\end{array}$ & $\begin{array}{c}\text { Staru terapija, } \\
p\end{array}$ & $\begin{array}{c}\text { Lāzerķirurǵija, } \\
p\end{array}$ & $\begin{array}{c}\text { Kriodestrukcija, } \\
p\end{array}$ \\
\hline Auss & $1,000 \mathrm{~ns}$ & $<0,001 * * *$ & $0,053 \mathrm{~ns}$ \\
\hline Lūpa & - & $<0,001 * * *$ & $0,048 *$ \\
\hline Acs plakstinsš & $1,000 \mathrm{~ns}$ & $1,000 \mathrm{~ns}$ & $1,000 \mathrm{~ns}$ \\
\hline Deguns & $0,590 \mathrm{~ns}$ & $0,326 \mathrm{~ns}$ & $<0,001 * * *$ \\
\hline Piere & $1,000 \mathrm{~ns}$ & $0,268 \mathrm{~ns}$ & $0,037 *$ \\
\hline $\begin{array}{l}\text { Galvas matainā } \\
\text { dal̦a }\end{array}$ & $0,394 \mathrm{~ns}$ & $0,556 \mathrm{~ns}$ & $0,629 \mathrm{~ns}$ \\
\hline Kakls & $1,000 \mathrm{~ns}$ & $1,000 \mathrm{~ns}$ & $1,000 \mathrm{~ns}$ \\
\hline Vaigs & $0,728 \mathrm{~ns}$ & $0,776 \mathrm{~ns}$ & $0,678 \mathrm{~ns}$ \\
\hline Zods & - & - & - \\
\hline
\end{tabular}

$p-$ Pearson $\chi^{2}$ vai Fisher's exact test; “-”-nebija pacientu ar recidīvu

\subsubsection{Prognostiskās BŠV recidīvu biežuma īpašības saistībā ar dažādām ārstēšanas metodēm, audzēja klīniski morfoloğisko formu, izmēru, precīzi norādītu anatomisko lokalizāciju un pacientu demogrāfiskajiem datiem}

Daudzfaktoru binārā loǵistiskā regresija lietota katrai ārstēšanas metodei atsevišķi. pētījumā izmantots loǵistiskās regresijas modelis pieciem neatkarīgiem mainīgajiem: klīniski morfoloǵiskajai formai, audzēja izmēram, precīzi norādītai audzēja lokalizācijai, pacienta dzimumam un vecumam. 
Operācija: modelis kopumā ir statistiski ticams būtiskuma līmen̄̄ $p<0,001$.

Binārās logistiskās regresijas vienādojums par recidīva veidošanās varbūtību pēc operācijas ir: logit (recidìva veidošanās varbūtība pēc operācijas) $=-1,293-0,482 \times$ pacienta vecums $+0,721 \times B \check{S} V$ izmērs.

Staru terapija: modelis kopumā ir statistiski ticams būtiskuma līmen̄̄ $p<0,001$. Binārās loǵistiskās regresijas vienādojums par recidīva veidošanās varbūtību pēc staru terapijas ir: logit (recid̄̄va veidošanās varbūtība pēc staru terapijas $)=-3,226-0,361 \times$ pacienta vecums $+1,699 \times k$ liniski morfologiskā forma.

Lāzerķirurğija: modelis kopumā ir statistiski ticams būtiskuma līmen̄̄ $p<0,001$. Binārās logiistiskās regresijas vienādojums par recidīva veidošanās varbūtību lāzerķirurǵijas gadījumā ir: logit (recidīva veidošanās varbūtība pēc lāzerķirurğijas $)=-1,655-0,184 \times$ lokalizācija $-0,502 \times$ pacienta vecums + $0,694 \times$ izmērs $+1,182 \times$ klīniski morfologiskā forma.

Kriodestrukcija: modelis kopumā ir statistiski ticams būtiskuma līmenī $p<0,001$. Binārās loǵistiskās regresijas vienādojums par recidīva veidošanās varbūtību kriodestrukcijas gadījumā ir: logit (recidīva veidošanās varbūtība pēc kriodestrukcijas) $=-1,185-0,453 \times$ lokalizācija $+1,2450 \times$ izmērs.

\subsubsection{Dažādu BŠV ārstēšanas metožu kopsavilkuma analīze.}

Dažādu BŠV ārstēšanas metožu kopējās analīzes veikšanai rezultāti ir apkopoti kopsavilkuma 2.12. tabulā. 
2.12. tabula

BŠV recidīvu biežums pēc dažādu ārstēšanas metožu lietošanas

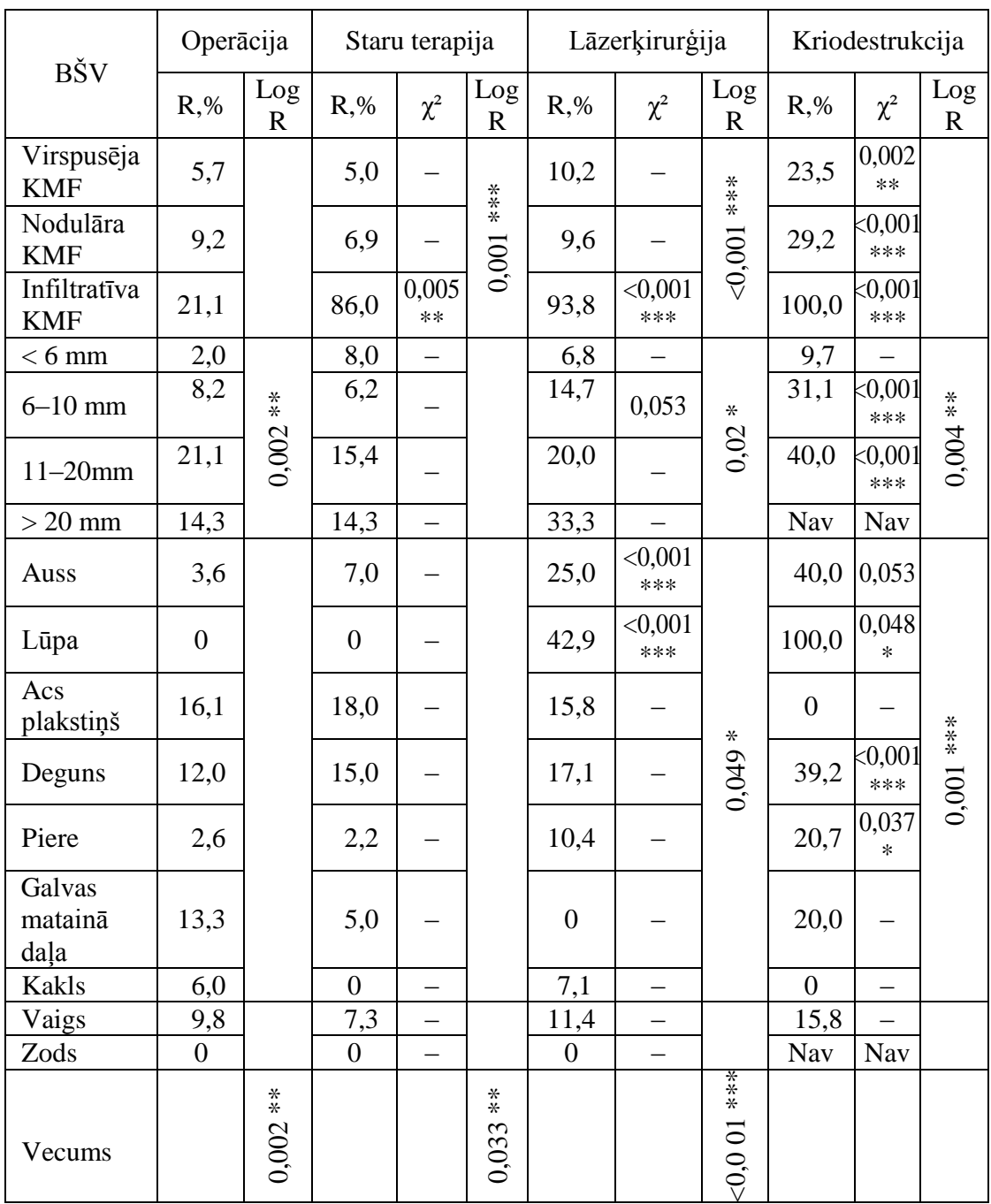

R, \% - recidīvu biežums; $\chi^{2}-$ Pearson $\chi^{2}$ (tabulā parādīit tikai statistiski ticami rezultāti, “- " rezultāts nav statistiski ticams); Log.R - logistiskā regresija; tabulā parādīti tikai tie mainīgie, kuriem ir statistiski ticama ietekme uz recidīvu veidošanos; Nav - nav gadījumu; KMF - klīniski morfologiskā forma; BŠV - bazālo šūnu vēzis 


\subsection{Dažādu ārstēšanas metožu efektivitātes salīdzinošā analīze saistībā ar ādas kosmētiskā defekta (rētas) izteiktības pakāpi}

Pēc nejaušības principa atlasīja 195 pacientu fotogrāfijas. Aprakstošās statistikas rezultāti par ādas kosmētiskā defekta (rētas) izteiktības pakāpes novērtēšanu pēc ārstēšanas veidiem ekspertu vērtējumā ir redzami 2.13. un 2.14. tabulā.

2.13. tabula

Ādas kosmētiskā defekta (rētas) izteiktības pakāpe ārstu un pacientu vērtējumā

\begin{tabular}{|l|c|c|c|c|}
\hline Ārstēšanas metode & $\begin{array}{c}\text { Vidējais, M } \\
(\bar{a} r s t i)\end{array}$ & $\begin{array}{c}\text { Vidējais, M } \\
\text { (pacienti) }\end{array}$ & $\begin{array}{c}\text { Mediāna, Me } \\
(\bar{a} r s t i)\end{array}$ & $\begin{array}{c}\text { Mediāna, Me } \\
\text { (pacienti) }\end{array}$ \\
\hline Operācija & 3,14 & 1,55 & 2 & 1 \\
\hline Staru terapija & 3,92 & 2,15 & 3 & 2 \\
\hline Lāzerkirurǵija & 2,69 & 1,56 & 2 & 1 \\
\hline Kriodestrukcija & 3,86 & 1,54 & 3 & 1 \\
\hline
\end{tabular}

Grupas iekšējās saskaņotības (ekspertu novērtējumu vienprātības noteikšanai izmantots Intraclass Correlation Coefficient (ICC). ICC vērtība ir vidēja $(0,65)$, norādot uz ekspertu viduvēju saskaņotību $(p<0,001 * * *)$.

Statistiski ticamu rezultātu noteikšanai ādas kosmētiskā defekta (rētas) izteiktības pakāpes vērtējumā pēc dažādiem ārstēšanas veidiem ir izmantota Kruskal-Wallis rangu dispersijas analīze (2.14. tabulā un 2.4. attelā).

2.14. tabula

Ādas kosmētiskā defekta (rētas) izteiktības pakāpes vērtējums

\begin{tabular}{|l|c|c|c|}
\hline Ārstēšanas metode & $\mathrm{n}$ & $\begin{array}{c}\text { Vidēja atzīme } \\
\text { (Mean rank) }\end{array}$ & $p$ \\
\hline Operācija & 58 & 80,89 & \multirow{3}{*}{$<0,001^{* * *}$} \\
\hline Staru terapija & 55 & 131,43 & \\
\hline Lāzerķirurğija & 43 & 56,16 & \multirow{2}{*}{} \\
\hline Kriodestrukcija & 39 & 122,44 & \\
\hline
\end{tabular}

$p$ - Kruskal-Wallis tests 


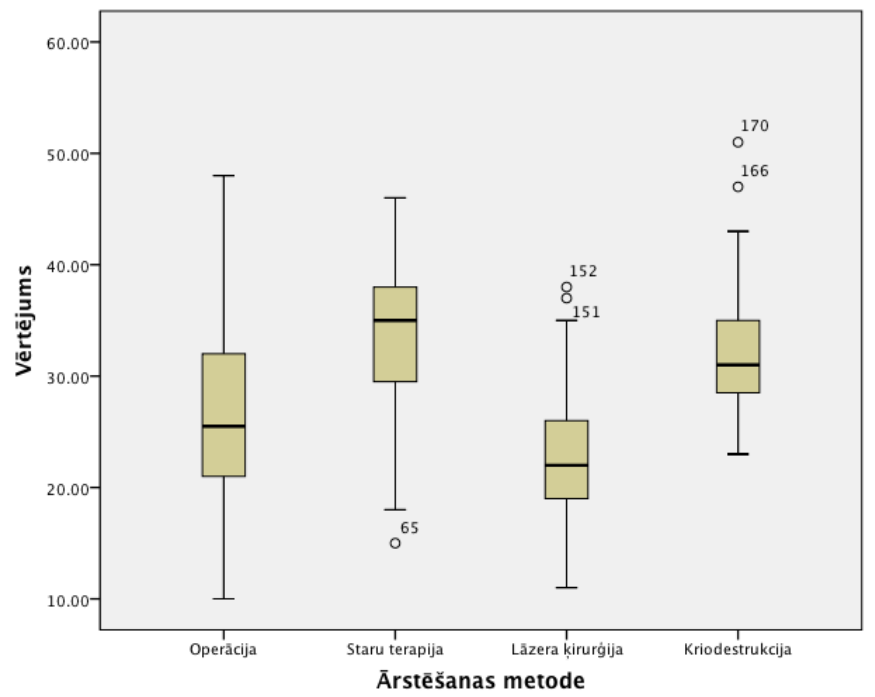

2.4. att. Ādas kosmētiskā defekta (rētas) izteiktības pakāpes vērtējuma analīzes rezultāti 


\section{DISKUSIJA}

\subsection{Sejas, galva un kakla BŠV klīniskās ainas un recidivēšanas īpatnību analīze}

Salīdzinot pētījuma rezultātus par sejas, galvas un kakla BŠV klīniskās ainas un recidivēšanas īpatnībām ar citu pasaules pētījumu rezultātiem, redzams, ka autora novērotās tendences darbā lielā mērā atbilst pasaules pētîjumos novērotajām tendencēm. Tomēr jāatzīmē, ka lielākajā dalıā pasaules pêtījumu tiek analizēti dati, kuri iegūti 5 gadu novērošanas laikā (vairākos darbos - 2-3 gadu laikā (Wooldridge at al. (1975), Bath-Hextall et al. (2014)). Salīdzinot darba rezultātus ar citu pētījumu rezultātiem, ir jāṇem vērā klasiskās BŠV recidīvu veidošanās īpatnības, kas konstatētas Rowe et al. (1989) darbā: apmēram $30 \%$ recidīvu veidojas pirmā novērošanas gada laikā, 50\% - otrajā gadā, 66\% - trešajā gadā un 18\% - turpmāko 6-10 gadu laikā. Šī darba ietvaros novērošanas vidējais laiks bija 8,5 gadi, tādēl recidīvu biežums bija nedaudz lielāks nekā minēts lielākajā dạ̧ā citu autoru darbu, kuros ir dati par BŠV recidivēšanas biežumu piecu vai mazāk gadu laikā. Minētais sakrīt ar McGovern et al. (1999) un Boztepe et al. (2004) pētījumu rezultātiem.

Darbā tika konstatēts, ka sejas, galvas un kakla BŠV recidīvu biežums vairāk nekā 5 gadu novērošanas periodā bija 13,02\%, kas atbilst rezultātiem lielākajā dạ̧ā publicēto pētījumu (Rowe et al. (1989), Silverman et al. (1991), Sartore et al. (2011), Nakayama et al. (2011), Chren et al. (2013)).

Atklātās likumsakarības par recidīvu biežumu saistībā ar klīniski morfoloǵisko formu, audzēja izmēru un precīzi norādītu anatomisko lokalizāciju kopumā atbilst citu pasaules pētījumu rezultātiem (Silverman et al. (1991), Zagrodnik et al. (2003), Caccialanza et al. (2013)). Visbiežāk recidīvi

veidojās pacientiem ar BŠV infiltratīvo formu: mūsu pētījumā - 61,36\% pacientu, citos pētījumos - no 27\% (Blixt et al. (2013)) līdz 61,8\% pacientu (Peres et al. (2012)). Pētījumā netika konstatēts atšķirīgs recidīivu biežums 
nodulārās $(10,82 \%)$ un virspusējās $(10,64 \%)$ klīniski morfoloǵiskās BŠV formas gadījumā - šie rezultāti atbilst Sexton et al. (1990), Emmett et al (1990) pētījumu rezultātiem, bet ir pretrunā ar Dandurand et al. (2006) pētījumu, kurā konstatēts, ka pacientiem ar nodulāru klīniski morfologisko BŠV formu recidīvi veidojās biežāk nekā pacientiem ar virspusēju formu.

Precīzai klīniski morfologiskās formas noteikšanai vislabāk ir izmantot mūsdienu neinvazīvās metodes - dermaskopiju (Altamura et al. (2010) [39]), ādas autofluorescences fotoizbalēšana (photobleaching) Ferulova et. al. (2012) [40]), multispektrālu attēlošanu (Diebele et al. (2012) [41]), un konfokālo lāzermikroskopiju (Ulrich et al. (2012) [42]). Turklāt diagnozes precīzai noteikšanai, it īpaši ja ir aizdomas par infiltratīvo BŠV formu, ir noteikti jāveic audzēja morfologiskā verifikācija pirms ārstēšanas uzsākšanas (Mosterd et al. (2009)).

Šì pētījuma ietvaros audzēji tika grupēti ne tikai saskaņā ar TNM klasifikāciju, kā tas ir pieņemts lielākajā dạ̦ā valstu, bet arī pēc audzēja izmēra atbilstoši Silverman et al. (1991) pētījumā sniegtajiem ieteikumiem un NCCN (2014) rekomendācijām, kur norādīti sekojoši audzēju izmēru diapazoni: audzējs < $6 \mathrm{~mm}, 6-10 \mathrm{~mm}, 11-20 \mathrm{~mm}$, audzējs $>20 \mathrm{~mm} \mathrm{[3,7].}$

Pētījums apstiprināja nepieciešamību grupēt audzējus atbilstoši minētajiem izmēriem, jo bija vērojams recidīvu biežuma statistiski ticams ( $p<$ 0,05) pieaugums, palielinoties audzēju izmēriem katrā nākamajā izmēru diapazona grupā. Šñ sakarība rada nepieciešamību precīzāk izvēlēties optimālo ārstēšanas metodi, it īpaši jautājumā par alternatīvās ārstēšanas metodes izvēli.

Šajā pētījumā visbiežāk tika diagnosticēti $6-10 \mathrm{~mm}$ lieli audzēji (64,67\%), otro vietu ieñēma audzēji, < $6 \mathrm{~mm}(19,01 \%)$, trešajā vietā 11-20 mm lieli audzēji un audzēji, > $20 \mathrm{~mm}-16,32 \%$. Ši tendence saskan ar citos pētījumos iegūtajiem rezultātiem - Avril et al. (1997) ( $\mathrm{n}=347: 6-10 \mathrm{~mm}$ lieli audzēji $-50 \%,<6 \mathrm{~mm}-11 \%, 11-20 \mathrm{~mm}$ lieli audzēji - 33\%, > $20 \mathrm{~mm}-$ $6 \%)$. Turpretī Moskalik et al. $(2010)(\mathrm{n}=2743)$ pētījumā audzēji $<10 \mathrm{~mm}$, bija 
34,67\%, 11-20 mm lieli audzēji - 57,45\%, audzēji > $20 \mathrm{~mm}-7,87 \%$ pacientu. Var domāt, ka lielais maza izmēra $(6-10 \mathrm{~mm})$ audzēju īpatsvars šajā pētījumā ir izglītojoši profilaktiskā darba rezultāts un liecina par pacientu agru vēršanos pēc medicīniskās palīdzības.

BŠV dalījums pēc anatomiskās lokalizācijas ir precīzāks, to apstiprināja arī pētījumā iegūtie rezultāti. Piemēram, lokalizācijām ar SSK-10 kodu C44.3 (deguns, piere, vaigs, zods) šì koda grupas ietvaros statistiski ticami $(p<0,05)$ atšksīrās recidīvu biežums - no 19,15\% deguna ādā līdz 0\% zoda ādā, kas jāṇem vērā, izvēloties piemērotu ārstēšanas metodi. Sejas, galvas un kakla rajoni tika sakārtoti dilstošā secībā atbilstoši recidīvu biežumam tajos: lūpa - 31,25\%, deguns $-19,15 \%$, acs plakstiņs $-15,94 \%$, auss $-10,9 \%$, vaigs $-10,5 \%$, galvas matainā daļa $-9,09 \%$, piere $-8,46 \%$, kakls $-4,17 \%$ un zods $-0 \%$. Šie rezultāti kopumā atbilst līdzīgu pētījumu rezultātiem (Mosterd et al. (2009), Pazdrowski et al. (2012), Goto et al. (2012)).

Vairākos rietumvalstu pētījumos (Silverman et al. (1991), Zak-Prelich et al. (2004), de Vries et al. (2012)) bija izdarīti secinājumi, ka ar sejas, galvas un kakla BŠV biežāk slimo vīrieši, turpretī Latvijā vērojama pretēja tendence 65,6\% mūsu pētījuma dalībnieku bija sievietes un tikai 34,4\% - vīrieši. Arī vairākās Austrumeiropas valstīs (Trakatelli et al. (2007) un Krievijāa (Снарская et al. (2005) veiktajos pētījumos secināts, ka ar sejas, galvas un kakla BŠV sievietes slimo biežāk nekā vīrieši. Uz šo tendenci ar sejas, galvas un kakla BŠV biežāk saslimt sievietēm, it īpaši līdz 40 gadu vecumam, norādīts arī Birch-Johansen et al (2010) pētījumā ar 30 gadu ilgu novērojumu periodu. Šīs tendences izvirza jaunas prasības profilakses jomā, prasības pēc savlaicīgas diagnostikas un efektīvas ārstēšanas.

Daži autori (Silverman et al. (1991), Veronese et al (2012), Cognetta et al. (2012)) ir pārliecināti, ka pastāv sakarība starp BŠV recidīvu biežumu un pacientu dzimumu - pēc viṇu datiem vīriešiem ir lielāks recidīvu biežums nekā 
sievietēm, tomēr mūsu pētîjumā šāda statistiski ticama atšķirība netika atklāta sievietēm recidīvi tika novēroti $13,4 \%$ gadījumu, vīriešiem $12,3 \%$ gadījumu.

Saslimstība ar sejas, galvas un kakla BŠV dažādās vecuma grupās Latvijā atbilst citu pasaules pētījumu rezultātiem - jo lielāks pacientu vecums, jo statistiski ticami lielāka saslimstība ar BŠV (Silverman et al. (1991), BathHextall et al. (2007), Telfer et al. (2008) un citi). Būtisks ir jautājums par recidīvu riska tendencēm saistībā ar vecumu - jaunāka gadagājuma cilvēkiem ir lielāks recidīvu veidošanās risks, turpretī vecāka gadagājuma cilvēkiem mazāks (jo lielāks pacientu vecums, jo retāk veidojas recidīivi). Vislielāko recidīvu skaitu mēs novērojām 41 - 60 gadus veciem pacientiem - tas atbilst analoǵisku pētījumu (Betti et al (2009), Skellett et al. (2012)) rezultātiem, bet atšķiras no Roudier-Pujol et al. (1999) pētījuma, kurā netika konstatētas statistiski ticamas atšķirības starp recidīvu biežumu pacientiem līdz 35 gadu vecumam un pacientiem pēc 35 gadu vecuma.

\subsection{Sejas, galvas un kakla BŠV ārstēšanas metodes}

Sejas, galvas un kakla BŠV ārstēšanas metožu daudzveidība ir liela un liels ir šai tēmai veltîto pētījumu skaits, tomēr optimālas BŠV ārstēšanas metodes izvēle joprojām ir diskusiju avots. Ārstēšanas metodes izvēles grūtības ir saistītas ar to, ka, lai gan no onkoloğijas viedokḷa šī slimība nav dzīvībai bīstama, tai ir raksturīgi bieži recidīvi. Pēc recidivēšanas audzējs kḷ̂̄st agresīvāks, tādējādi veidojas t.s. apburtais loks: "recidīvs - ārstēšana - jauns recidīvs - jauna ārstēšana”. Tas var izraisīt orgāna funkciju traucējumus, pasliktināt rētas ārējo izskatu, tā sagādājot pacientam papildu pārdzīvojumus un pazeminot dzīves kvalitāti. Saskaņā ar Holfeld et al. (1990), Essers et al. (2007), Fagundes et al. (2012) viedokli, kosmētiskais defekts galvas ādā un it īpaši sejas ādā var izraisīt psihoemocionālus pārdzīvojumus un noteiktos gadījumos - smagu depresiju. 
Izvēloties ārstēšanas metodi, ir svarīgi, lai audzēja šūnu pilnīgas likvidācijas gadījumā tiktu maksimāli saglabāta attiecīgā orgāna funkcija, būtu arī labs kosmētiskais rezultāts un tiktu saglabāts sejas individuālais reljefs. Tādēḷ, izvēloties piemērotu sejas, galvas un kakla BŠV ārstēšanas metodi, ir jāņem vērā gan audzēju raksturojošie faktori, pacienta vecums un dzimums, gan paredzamā ādas kosmētiskā defekta (rētas) izteiktības pakāpe.

Nepieciešamība pēc "zelta vidusceḷa" starp efektivitāti (retiem recidīviem) un labu kosmētisko rezultātu, pavēra iespēju plašai alternatīvo metožu attīstībai. BŠV efektīvu alternatīvu ārstēšanas metožu meklējumi pēdējos gados ir kḷuvuši par pirmā plāna tēmu daudzos pētījumos (Wang et al (2001), Ozolins et al. (2010), Amini et al. (2010), Attili et al. (2012)). Lai arī lielākā daļa alternatīvo metožu dod labu kosmētisko rezultātu ar vienkāršākām procedūrām, katrā konkrētā gadījumā būtu jānovērtē šo metožu lietošanas adekvātums, ņemot vērā recidīvu biežumu vairāk nekā 5 gadu novērošanas laikā. Lielākajā daḷā pētījumu autori saista recidīvu veidošanās iemeslus ar neadekvāti izvēlētas alternatīvās ārstēšanas metodes lietošanu (Silverman et al. (1991), Ko et al. (1992), Telfer et al. (2008)).

Pētījumā tika veikta četru BŠV ārstēšanas metožu (operācija, staru terapija, lāzerķirurğija, kriodestrukcija) salīdzinošā analīze, kā arī noteiktas stingras robežas katras metodes lietošanā, atklājot riskus, norādot uz ierobežojumiem katras metodes lietošanā, saistībā ar vairākiem audzēja faktoriem - klīniski morfologisko formu, izmēru, precīzi norādītu anatomisko lokalizāciju un paredzamo kosmētisko rezultātu.

\subsection{Sejas, galvas un kakla BŠV ķirurğiskas ārstēšanas iespējas}

Par drošāko BŠV ārstēšanas veidu ir atzīta operācija (it īpaši Mohs mikrogrāfiskā operācija, kas Latvijā pagaidām netiek veikta). BŠV gadījumā recidīvu biežums 5 gadu novērošanas laikā pēc Mohs operācijas ir 0,7-3\%, pēc operācijas ar rezekcijas līnijas histologísko kontroli 2-14\%. Šajā pētījumā 
recidīvu biežums pēc operācijas bija 9,2\%: virspusējas formas BŠV gadījumā $5,7 \%$, nodulāras formas $-9,2 \%$, infiltratīvas formas $-21,1 \%$. Pēc autora domām, tas varētu būt saistīts ar izlases specifiku (novērošanas periods ilgāks nekā 5 gadi (vidēji - 8,5 gadi), kā rezultātā recidīvu skaits ir lielāks), ar jēdzieniem - audzēja klīniskās robežas (malas) (clinical margin) un ķirurğiskās malas (surgical margin (Abide et al., 1984)), un arī ar klīniskās robežas noteikšanas grūtībām (Telfer et al., 2008)). Diemžēl ambulatoro pacientu medicīniskajās kartēs informācija par robežas noteikšanas grūtībām nebija atrodama, kā arī trūka precīzas informācijas par ķirurǵiski nosakāmām robežām.

Analizējot recidīvu biežumu, būtiska nozīme ir atkāpei no audzēja klīniskajām malām operācijas laikā. Pēc Griffiths et al. (2007), Malik et al. (2010), Cecchi et al. (2011), neradikālas operācijas gadījumā recidīvu biežums ir lielāks - līdz 41\%. Pētījumos konstatēts, ka minimālajai atkāpei jābūt 4-5 mm (Kimyai-Asadi et al. (2005)), bet infiltratīvu audzēju gadījumā - pat līdz 10-15 mm (Breuninger H. un Dietz K. (1991). Histologisko slēdzienu analīzes laikā LOC netika atklāta informācija par precīzām atkāpēm no audzēja klīniskajām malām. Pēc Royal College of Pathologists (2012) ekspertu domām, ir svarīga precīza pēcoperācijas robežu kontrole: $<1 \mathrm{~mm}, 1-5 \mathrm{~mm},>5 \mathrm{~mm}$ no audzēja malām. Iespējams, ka tieši ar šīs precīzās pēcoperācijas atkāpes kontroles trūkumu var izskaidrot salīdzinoši biežos recidīvus 11-20 mm lieliem audzējiem pēc operācijas - mūsu pētījumā 21,1\% gadījumu, turpretim audzējiem līdz $6 \mathrm{~mm}-2,0 \%$ un 6-10 mm lieliem audzējiem - 8,2\%. Ja audzējs ir liela izmēra, ķirurgiem ir jāatrod līdzsvars starp efektivitāti (zemu recidīvu biežumu), orgāna funkciju saglabāšanu un tendenci veikt pēc iespējas saudzējošāku griezumu, it īpaši acs plakstiņu, lūpas, deguna vai auss rajonā. Visbiežāk recidīvi pēc operācijas veidojās acs plakstiņā (16,1\%), galvas matainajā daḷā (13,3\%) un deguna ādā (12,0\% pacientu). No operācijas veikšanas viedokḷa šīs lokalizācijas ir uzskatāmas par sarežǵītām un lielākoties 
pēc tām ir nepieciešama rekonstruktīva operācija ar ādas pārstādī̌sanu. Mūsu pêtījumā tomēr konstatēts neliels recidīvu biežums klasiski "sarežğîtu" lokalizāciju gadījumos - aus̄̄ 3,6\% pacientu un lūpā $0 \%$.

\subsection{Staru terapijas iespējas sejas, galvas un kakla BŠV ārstēšanā}

Darbā aprakstītie recidīvu biežuma salīdzinošās analīzes rezultāti dažādu sejas, galvas un kakla BŠV ārstēšanas metožu pielietošanas gadījumos atspoguḷo zinātniskajā pasaulē pastāvošās pretrunas un strīdus. Viens tāds strīdīgs jautājums, kuru padarīja aktuālu NCCN ekspertu viedokḷa publicēšana pēdējos gados (2010), ir jautājums par operācijas un staru terapijas efektivitātes salīdzināšanu. Lielākā daļa autoru (Avril et al,, Rowe et al., Zagrodnik et al. un citi) uzskata operāciju par "zelta standartu”, t.i., par efektīvāku ārstēšanas metodi nekā staru terapija, tomēr vairākos pētījumos ir norādīts, ka staru terapija var būt tikpat efektīva kā operācija: Olschewski et al. (2006) pētījumā $(\mathrm{n}=104)$ recidīvu biežums bija $0 \%$. Cognetta et al. $(2012)$ pētījumā $(\mathrm{n}=712)$ piecu gadu laikā recidīvu biežums bija 4,2\%, bet Caccialanza, M. et al. (2013) pētījumā $(\mathrm{n}=986)$ piecu gadu laikā $-5,47 \%$.

Recidīvu biežums pēc staru terapijas visām BŠV formām (izņemot infiltratīvo) bija mazāks nekā pēc operācijas: virspusējas formas gadījumā $5,0 \%$ (pēc operācijas - 5,7\%), nodulāras formas gadījumā - 6,9\% (pēc operācijas - 9,2\%). Līdzīgs vai pat mazāks recidīvu biežums bija dažādu izmēru diapazonu audzējiem: ja audzēji bija $<6 \mathrm{~mm}$, recidīvi bija

8,0\% pacientu (pēc operācijas 2,0\%), 6-10 mm lielu audzēju gadījumā $-6,2 \%$ pacientu (pēc operācijas $-8,2 \%$ ), 11-20 mm lielu audzēju gadījumā - 15,4\% pacientu (pēc operācijas - 21,1\%). Veicot salīdzinošo analīzi par BŠV recidīvu biežumu dažādām audzēju lokalizācijām, bija redzams, ka pēc staru terapijas salīdzinājumā ar operāciju recidīvi retāk veidojās galvas matainajā daḷā - 5,0\% pacientu (pēc operācijas - 13,3\%) un vaigu ādā - 7,3\% pacientu (pēc operācijas - 9,8\%). Lai arī darbā netika novērotas statistiski 
ticamas atškirīibas starp recidīvu biežumu pēc operācijas un pēc staru terapijas (izņemot BŠV infiltratīivo formu), šos datus būtu vēlams pētīt papildus.

Staru terapijai ir noteikti ierobežojošie faktori: vecuma ierobežojums $N C C N$ un $E D F$ rekomendē staru terapiju pacientiem veikt tikai no 60 gadu vecuma, jo tā var inducēt ādas vēzi pēc 15-20 gadiem; staru terapijas lietošanas grūtības "sarežǵītu” lokalizāciju gadījumos - acs plakstiņam, degunam, ausi; staru terapija izraisa dažādus ādas kosmētiskus defektus - alopēciju galvas matainajā daļā, reizēm teleangiektāzijas, staru dermatītu un izčūlojumus līdz pat pēcstaru ādas nekrozei.

Tomēr noteiktos gadījumos (pacienta izvēlēta terapija, kontrindikācijas operācijai, adekvāts vecums) un ievērojot noteiktus nosacījumus (frakcionētā veidā, mazās devās 2-3 Gy) staru terapija var būt efektīvāka nekā operācija. Pēc autora domām, vajadzētu precizēt, kuros gadījumos staru terapija ir optimālāka nekā operācija - piemēram, liela izmēra virspusējas un nodulāras formas audzēju gadījumā vietās, kur ir pārāk sarežğīta piekḷuve, lai veiktu operāciju. Olschewski et al. (2006) sava pētījuma secinājumos rekomendē šādu ārstēšanas variantu - $5 \times 3$ Gy/nedēḷā līdz kopējai devai 57 Gy - kā standarta terapiju sejas, galvas un kakla BŠV gadījumos. Minētās terapijas gadījumā recidīvi veidojās reti.

Šī pētījuma ietvaros tika konstatēts, ka sejas, galvas un kakla BŠV infiltratīvās formas gadījumā recidīvu biežums pēc operācijas $(21,1 \%)$ statistiski ticami atšķiras no recidīvu biežuma pēc staru terapijas (86,0\%), kas atbilst citu līdzīgu pētījumu rezultātiem (Zagrodnik et al. (2003), Cognetta et al. (2012)). Pētījuma autori uzskata infiltratīvo klīniski morfoloǵisko formu par recidīvu riska papildu faktoru, bet Cognetta A. et al. rekomendē izmantot citu staru terapijas veidu - apstarošanu elektronu režīmā sejas, galvas un kakla BŠV infiltratīvās formas gadījumā. Tas liecina par nepieciešamību noteikt klīniski morfologisko formu pirms ārstēšanas uzsākšanas, kā arī veikt papildu diagnostiskus izmeklējumus klīniski morfoloǵiskās formas precizēšanai un 
audzēja infiltrācijas dziļuma noteikšanai (piemēram, ādas augstfrekvences ultrasonoskopija), kas ļautu izvēelēties optimālāko staru terapijas metodi.

\subsection{Lāzerķirurğijas iespējas sejas, galvas un kakla BŠV ārstēšanā}

Pēdējās desmitgadēs lāzerḳirurğija ir kḷuvusi plaši pazīstama kā BŠV ārstēšanas metode, pateicoties vairākām priekšrocībām salīdzinājumā ar operāciju un staru terapiju: minimāli asins zudumi, iespēja ārstēt pacientus, kuri lieto antikoagulantus (kas savukārt var būt kontrindikācija plašai operācijai), saudzējošs lokālas iedarbības efekts, labs kosmētiskais rezultāts un metodes ekonomiskums (Moskalik et al. (2009), Tran et al. (2012)).

Tomēr pētījumā iegūtie dati liecināja, ka par spīti metodes priekšrocībām, tai ir arī noteikti ierobežojumi. Recidīvu biežums pēc lāzerķirurgijijas ir 13,8\%, kas ir vairāk nekā pēc operācijas $(9,2 \%)$ un staru terapijas $(8,5 \%)$. Šì atškirīiba nav statistiski ticama, tomēr, salīdzinot recidīvu biežumu saistībā ar formu, izmēru un precīzu anatomisko lokalizāciju, bija vērojama statistiski ticama atšķ̧irība operācijas un lāzerķirurğijas gadījumā.

Statistiski ticamas recidīvu biežuma atšķirības pēc lāzerķirurğijas un operācijas tika novērotas infiltratīvās klīniski morfologiskās formas gadījumā 93,8\% pacientu, pēc operācijas - 21,1\%. Virspusējas un nodulāras formas audzējiem statistiski ticamu recidīvu biežuma atškirību pēc operācijas un lāzerķirurǵijas nebija (virspusējā forma: pēc lāzerķirurǵijas - 10,2\%, pēc operācijas - 5,7\%; nodulāra forma: pēc lāzerķirurg̣ijas recidīivi 9,6\% pacientu, pēc operācijas - 9,2\%). Bieži recidīvi pēc lāzerḳirurǵijas tika novēroti, ja audzēja izmērs bija 11-20 mm (20,0\%) un lielāks par $20 \mathrm{~mm}(33,3 \%)$. Tomēr atšķirības recidīvu biežumā pēc operācijas 11-20 mm lielajiem audzējiem nebija statistiski ticamas, jo arī pēc operācijas recidīvi veidojās l̦oti bieži $(21,1 \%)$. Bez tam izteiktais recidīvu biežums statistiski ticami atšķīrās lūpas BŠV (42,9\%) un auss BŠV gadījumos (25,0\%). 
Iegūtie dati liecina, ka lāzerḳirurğijas lietošana ir ierobežota tādēḷ, ka šī metode ir efektīva virspusējas un nodulāras klīniski morfologiskās formas audzēju gadījumā, ja audzējs $<10$ mm (diskutabls ir jautājums par 11-20 mm lieliem audzējiem), ja audzējs lokalizēts deguna, pieres, galvas matainās daļas, kakla, vaiga un zoda ādā. Lāzerķirurğijas lietošana ir ierobežota, ja ir infiltratīvs BŠV, audzējs > 20 mm, kā arī lūpas un auss BŠV gadījumā.

Iegūtie dati kopumā saskan ar citu pētījumu datiem un atšķiras vienīgi pēc lāzerķirurğijas izmantošanas diapazona, piemēram, Moskalik et al. (2010) savā pētījumā pārliecināti apgalvo, ka lāzerķirurǵija ir lietojama T1N0M0 un T2N0M0 BŠV ārstēšanā, tomēr arī viņa pētījumā ir norādīts, ka lāzerķirurğijas izmantošana ir būtiski ierobežota tad, ja audzēja dziļums nav lielāks par $5 \mathrm{~mm}$. Turpretī Korejā veiktā pētījumā (Jung et al. (2011)) tika konstatēts, ka pēc lāzerķirurǵijas recidīvi veidojas "nemanāmi” (ir garāks audzēja attīstības intervāls līdz tā diagnosticēšanai), to histologiskā forma ir agresīvāka un recidīvu ārstēšanai ir nepieciešams vairāk Mohsa mikrogrāfiskās ķirurğijas ciklu, nekā pirmreizējas BŠV ārstēšanas gadījumā. Tomēr nav īsti korekti salīdzināt pirmreizēju BŠV un tā recidīvu, jo ir zināms, ka recidivējušie audzēji mēdz būt agresīvāki (Boulinguez et al. (2004)). Bez tam pētījumā ir akcentēts pieņēmums, ka ārstiem, kuri veica lāzerķirurğiju, trūka adekvātu zināšanu dermatolog̣ijā, tādēḷ viṇi varēja BŠV traktēt kā labdabīgu audzēju (seborejas keratozi vai nevusu) - tas visdrīzāk varētu liecināt nevis par konkrētās metodes neefektivitāti, bet gan par skrupulozākas diagnostikas nepieciešamību un atbilstošu ārstu sagatavotību, kuri veic BŠV ārstēšanu.

Vislielākais trūkums lāzerķirurğijas izmantošanā ir audzēja morfologiskās verifikācijas neiespējamība pēc pabeigtas procedūras, kā arī standartizētas ārstēšanas metodikas trūkums un augstāk aprakstīto šīs metodes izmantošanu ierobežojošo faktoru ignorēšana. 


\subsection{Kriodestrukcijas iespējas sejas, galvas un kakla BŠV ārstēšanā}

Tā kā BŠV lielākoties tiek diagnosticēts vecāka gadagājuma cilvēkiem (šajā pētîjumā - 71\% pacientu bija vecāki par 61 gadu), kuriem bieži mēdz būt somatiskas slimības, vēlams izmantot mazāk traumatiskas sejas, galvas un kakla BŠV ārstēšanas metodes. Viena no šādām metodēm ir kriodestrukcija.

Tomēr pētījuma rezultāti liecina, ka visbiežāk recidīvi veidojās tieši pēc kriodestrukcijas - 26,7\% pacientu - un šis rādītājs statistiski ticami atšķīās no recidīvu biežuma pēc operācijas $(9,2 \%)$, staru terapijas $(8,5 \%)$ un lāzerķirurgijijas (13,8\%). Turklāt, atšķirīibā no lāzerķirurǵijas, kriodestrukcijas gadījumā bieži recidīvi bija vērojami visu BŠV klīniski morfolog̣isko formu gadījumos (virspusējas formas gadījumā - 23,5\% pacientu, nodulāras - 29,2\%, infiltratīvas formas gadījumā - 100\% pacientu) un visiem audzējiem, kuri bija lielāki par 6 mm. Iegūtie rezultāti saskan ar starptautisku pētījumu rezultātiem, piemēram, Hall et al. (1986) pētījumā pēc kriodestrukcijas recidīvi bija 39\% pacientu, Thissen et al. (2000) pētījumā - 8,2\% pacientu. Šajā pētījumā kriodestrukcijai bija visšaurākais izmantošanas diapazons - šie rezultāti saskan ar citu pētījumu datiem: Thissen et al. (2000) rekomendēja veikt kriodestrukciju pacientiem, kam nav iespējama operācija, un tikai virspusējas un nodulāras klīniski morfoloǵiskas formas gadījumā, ja audzējs ir maza izmēra (līdz 10 mm) un lokalizēts acs plakstiņa ādā. Pētījumā pēc tādiem kritērijiem kā precīza audzēja anatomiskā lokalizācija un izmērs statistiski ticami atšḳīrās recidīvu biežums pēc operācijas no recidīvu biežuma pēc kriodestrukcijas. Padziļināta analīze atklāja, ka pēc kriodestrukcijas lūpas BŠV recidīvi bija 2 gadījumos no 2 (100\%), auss BŠV recidīvi - 2 gadījumos no 5 (40,0\%), deguna ādas BŠV recidīvi - 20 gadījumos no 51 (39,2\%); 6-10 mm lieli audzēji recidivēja 31,1\% gadījumu, 11-20 mm lieli audzēji - 40,0\% gadījumu, un visi šie lielumi statistiski ticami atšķ̄īās no attiecīgajiem lielumiem pēc operācijas. 
Dažos pētījumos ir izteikta visnotal optimistiska prognoze par kriodestrukcijas izmantošanu sejas, galvas un kakla BŠV ārstēšanā. Kuflik un G.Gage (1991), Kuflik, E. (2004) pētījumos, analizējot 30 gadu ilgu pieredzi kriodestrukcijas izmantošanā BŠV ārstēšanā, konstatēja, ka 5 gadu laikā recidīvi veidojās 1-2\% pacientu un neatrada apstiprinājumu anatomiskās lokalizācijas saistībai ar iznākumu. Tomēr, analizējot pētījumu izlasi, var secināt, ka ārstēšanas pozitīvie rezultāti ir saistīti ar pacientu atlases precizitāti kriodestrukcijai: pētījumā iekḷāva tikai tos pacientus, kuru audzēji "atbilst tam, lai viņus ārstētu ar kriodestrukciju" [43], kā arī pacientus, kuru audzējiem bija labi nosakāmas klīniskās robežas.

Pēc autora domām, kas balstītas uz veikto pêtījumu un personīgo 30 gadu ilgo pieredzi onkologijāâ, un saskaņā ar citu pasaulē veikto pētījumu rezultātiem pareiza ir atziṇa, ka katras ārstēšanas metodes efektivitāte ir atkarīga ne tikai no šīs metodes tehniskajām iespējām, bet arī no precīzas pacientu atlases noteiktajai ārstēšanas metodei. Tas nozīmē, ka: 1) Ir jāzina ierobežojošie un riska faktori katrai ārstēšanas metodei, precīzi norādījumi un kontrindikācijas šīs metodes lietošanā; 2) Ir svarīgi adekvāti un precīzi diagnosticēt audzēju pirms ārstēšanas uzsākšanas: pareiza klīniski morfoloǵiskās formas diagnostika, precīza audzēja malu noteikšana, nepieciešamības gadījumā papildu diagnostisko procedūru (dermaskopijas, augstfrekvences ādas ultrasonoskopijas, konfokālās lāzermikroskopijas) un obligāti - audzēja morfoloǵiskās verifikācijas veikšana; 3) Ir nepieciešama izpratne par dažādu faktoru savstarpējo mijiedarbību: sociāli demogrāfiskajiem faktoriem (pacienta dzimumu, vecumu), anamnēzes datiem (iespējamās blakusslimības), audzēja klīniskajām īpašībām un diagnostikas rezultātiem. Precīzi atlasot katrai konkrētai ārstēšanas metodei piemērotus pacientus ar audzējiem, var samazināt recidīvu veidošanos līdz minimumam. 


\section{7. Ādas kosmētiskā defekta (rētas) izteiktības pakāpe}

80-90\% bazālo šūnu vēžu (BŠV) lokalizējas sejas, galvas un kakla ādā, tādēḷ svarīgi ir izvēlēties ārstēšanas metodi, ar kuras palīdzību iespējams gan pilnībā likvidēt audzēju, gan nodrošināt labu kosmētisko rezultātu, saglabājot orgānu funkciju un sejas individuālo reljefu. Pēc Shah et al. (2011) un Fagundes et al (2012) pētījumu datiem, visi sejas ādas BŠV var izraisīt dažādu pakāpju ādas kosmētisku defektu. Šie vizuālie defekti negatīvi ietekmē slimnieku dz̄ives kvalitāti, iespaido viṇu psihisko stāvokli un var izraisīt psihopatologiiskas reakcijas (Pragnell J. un Neilson J. (2010)). Pēdējo 10 gadu laikā daudzos pētījumos tiek likts akcents ne tikai uz ārstēšanas metodes efektivitāti, bet arī uz labu kosmētisko rezultātu. Šo mērķu sasniegšana un orgāna funkciju saglabāšana ir uzdevumi, par kuru realizēšanu ir atbildīgs ārsts, izvēloties konkrēto ārstēšanas metodi (Maize et al. (2005)).

Sejas ādas reljefs ir ļoti sarežğīits un tādēl ir sarežǵīti veikt plašas operācijas. Visas BŠV ārstēšanas metodes tā vai citādi noved pie sejas ādas kosmētiska defekta veidošanās, un katrai ārstēšanas metodei ir savas "vājās" vietas. Veicot operāciju, ir nepieciešama vismaz $5 \mathrm{~mm}$ liela atkāpe no redzamajām audzēja malām, bet infiltratīvas formas gadījumā ir nepieciešama plašāka atkāpe (vismaz līdz 10-15 mm), pēc kuras būs nepieciešams veikt plastisku rekonstruktīvu operāciju. Pēc galvas matainās dạ̦ā, lūpas, auss ļaundabīgu audzēju operācijas defektu korekcija var radīt problēmas plastikas ķirurgiem un mutes, sejas un žokḷu ķirurgiem. Pēc Norman et al (2009) pētījuma datiem, arī deguna zonā operācija var būt tehniski sarežǵîta un radīt kosmētiskus defektus un funkciju traucējumus. Pēc Paoli et al. (2011) pētījumu datiem, šo zonu anatomisko īpatnību, iespējamo estētisko problēmu un funkcionālo traucējumu dēḷ ir nepieciešama augsta precizitāte plastiskās ķirurğijas operācijas laikā. Staru terapija izraisa dažādu ādas kosmētisku defektu veidošanos - hronisku staru dermatītu, ādas distrofiju, pigmentācijas 
izmaiņas, eritematozu laukumu parādīšanos. Ir novērots, ka sākotnēji labs kosmētisks rezultāts pēc kāda laika var pasliktināties. Pēc Paavilainen et al. (2007) datiem, veicot acs plakstiņa rajona apstarošanu, nereti rodas staru terapijas komplikācijas - staru dermatîts, konjunktivīts un katarakta. Pēc audzēja likvidācijas ar lāzerķirurğiju paliek laukums bez ādas seguma, kura dzīšanas procesā veidojas rēta, kura izceḷas uz apkārtèjās ādas fona (Trelles et al. (1996)). Par kriodestrukcijas metodes nepilnībām var uzskatīt krionekrozes sekas un brūces ilgstošu epitelizāciju, bet lūpas vai acs plakstiņa BŠV gadījumā pēc rētas izveidošanās notiek blakusesošo anatomisko rajonu deformācija (Kuijpers et al. (2007)).

Pētījumā atseviškss mērķis bija ādas kosmētiskā defekta (rētas) izteiktības pakāpes salīdzinošā analīze, izmantojot ekspertu vērtējumu (eksperta lomā gan ārsti, gan pacienti). Rezultātā tika noskaidrots, ka katras ārstēšanas metodes gadījumā ādas kosmētiskā defekta (rētas) izteiktības pakāpe ir atšķirīga un šīs atšķirības ir statistiski ticamas $(p<0,05)$. Pēc ekspertu domām, viszemākā ādas kosmētiskā defekta (rētas) izteiktības pakāpe bija lāzerķirurgíjas rezultātā (salīizinot vidējos vērtējumus: $M=2,69$ ), otrajā vietā - operācija $(M=3,14)$, trešajā vietā - kriodestrukcija $(M=3,89)$ un pēdējā vietā ar visizteiktāko ādas kosmētisko defektu (rētu) - staru terapija (M = 3,92), kas atbilst citu pētījumu rezultātiem.

Petit et al. (1999) (n = 347) salīdzināja kosmētisko rezultātu pēc 48 mēnešiem pēc operācijas un staru terapijas. Pētījumā secināts, ka, pēc neatkarīgo ekspertu domām, kosmētiskais rezultāts pēc operācijas ir labāks nekā pēc staru terapijas, kas saskan arī ar mūsu pētījuma rezultātiem. Turpretī Caccialanza et al. (2009), analizējot staru terapijas rezultātus ( $\mathrm{n}=671)$, secināja, ka kosmētiskais rezultāts pēc staru terapijas bija "labs" vai "pieņemams" (pēc 3 punktu skalas) 96,84\% ar staru terapiju ārstēto pacientu. Tomēr pētījuma rezultāti netika salīdzināti ar citu ārstēšanas metožu rezultātiem un par ekspertiem bija izvēlēti tie paši ārsti, kas iepriekš veica staru terapiju, 
tādējādi netika izslēgts subjektīvisma faktors. Kosmētiskā rezultāta vērtēšanai tika izvēlēti neatkarīgi eksperti. Vērtēšanai tika iesniegtas visas iespējamās pēc BŠV ārstēšanas izveidojušos rētu fotogrāfijas, kas, pēc autora domām, ir metodolog̣iski korektāk, jo l̦auj izvairīties no subjektīvisma ekspertu vērtējumos un sniedz plašas salīdzināšanas iespējas. Moskalik et al. (2009) ( $\mathrm{n}=3346)$ konstatēja "pieņemamu” kosmētisku rezultātu pēc lāzerķirurğijas. Tomēr arī šajā pētījumā netika veikta dažādu ārstēšanas metožu kosmētiskā rezultāta salīdzinošā analīze un vērtējumus sniedza tie paši ārsti, kuri bija veikuši šo ārstēšanu. Thissen et al (2000) (n = 96) salīdzināja operācijas un kriodestrukcijas kosmētisko rezultātu 12 mēnešu laikā pēc ārstēšanas un secināja, ka kosmētiskais rezultāts pēc operācijas ir labāks nekā pēc kriodestrukcijas.

Pacienti, kas izteica viedokli par savu kosmētisko rezultātu, sniedza pozitīvākus vērtējumus nekā ārsti eksperti: operācijai attiecīgi $\mathrm{M}_{\mathrm{pac}}=1,55$; $\mathrm{M}_{\text {eksp }}=3,14$; staru terapijai $\mathrm{M}_{\mathrm{pac}}=2,15 ; \mathrm{M}_{\text {eksp }}=3,92$; lāzerķirurǵijai $\mathrm{M}_{\mathrm{pac}}=1,56 ; \mathrm{M}_{\mathrm{eksp}}=2,69 ;$ kriodestrukcijai $\mathrm{M}_{\mathrm{pac}}=1,54 ; \mathrm{M}_{\mathrm{eksp}}=3,86$, kas atbilst arī citu pētījumu datiem (Rhee et al (2004), Steinbauer et al. (2011)). Raksturīgi, ka ekspertu-pacientu un ekspertu-ārstu novērtējumu tendence sakrīt (lāzerķirurğija un operācija novērtētas labāk nekā kriodestrukcija un staru terapija).

\subsection{Iespējamā rezultātu ekstrapolācija citām ārstēšanas metodēm BŠV ārstēšanai}

Pētījuma ietvaros tika salīdzinātas četras sejas, galvas un kakla BŠV ārstēšanas metodes - operācija, staru terapija, lāzerķirurǵija un kriodestrukcija (atstājot bez ievērības tādas ārstēšanas metodes kā Mohsa mikrogrāfiskā ķirurğija, fotodinamiskā terapija, terapija ar imunologiskās reakcijas modificētāju Imiquimod), tomēr, ņemot vērā šajā darbā konstatētās kopējās tendences, ir iespējams veikt šî pētījuma rezultātu ekstrapolāciju arī uz citām 
ārstēšanas metodēm. Piemēram, pēc audzēja ārstēšanas recidīvu veidošanās iespēja (varbūtība) ir jo lielāka, (1) jo sarežğîtāka ir audzēja klīniski morfologiskā forma (virspusēja - nodulāra - infiltratīva), (2) jo lielāks ir audzēja izmērs, (3) kā arī noteiktu lokalizāciju - lūpas, auss, acs, deguna BŠV gadījumos. Tas liecina par nepieciešamību izvēlēties mazāk "kosmētisku" un ekonomisku, toties efektīvāku ārstēšanas metodi - tādu tradicionālu metodi kā operāciju (un atsevišķos gadījumos - staru terapiju).

Izvēloties piemērotu ārstēšanas metodi katrā konkrētā gadījumā, ir īpaši jāapsver iespēja lietot saudzīgāku alternatīvu ārstēšanas metodi. Pats svarīgākais ir pareizi noteikt BŠV klīniski morfologiisko formu pirms ārstēšanas uzsākšanas, jo tas l̦auj adekvāti novērtēt riska faktorus un prognozēt iznākumu katras konkrētās ārstēšanas metodes izvēles gadījumā.

\subsection{Attīstības perspektīvas un tālāko pētījumu iespējas}

Šî pētījuma ietvaros noteiktas ārstēšanas metodes izvēles kritēriji bija sejas, galvas un kakla BŠV klīniski morfoloǵiskā forma, audzēja izmērs, precīza anatomiskā lokalizācija, kā arī pacienta sociāli demogrāfiskie dati (dzimums, vecums) un ādas kosmētiskā defekta (rētas) izteiktības pakāpe (ārstēšanas kosmētiskais rezultāts). Pēc Griffiths et al. (2007), Malik et al. (2010), Cecchi et al. (2011) datiem, šos kritērijus būtu vēlams papildināt ar tādu faktoru kā "klīniskās un ķirurğiskās robežas", jo tieši klīnisko robežu noteikšanas grūtības kopā ar citiem faktoriem var būt svarīgas, izvēloties ārstēšanas metodi. Tomēr papildu main̄̄gā iekḷaušanai pētījumā būtu nepieciešams padziḷināts apskats.

Ieguldījumu varētu sniegt pētījums par BŠV kombinēto ārstēšanas metožu iespējām, kas apvienotu tradicionālās un alternatīvās ārstēšanas metodes - piemēram, lāzerķirurgíiju un operāciju, lāzerķirurǵiju un terapiju ar Imiquimod, Imiquimod un kriodestrukciju, fotodinamiskās terapijas kombināciju ar operāciju vai lāzerḳirurğiju. Tas varētu būt īpaši svarīgi, ja BŠV 
lokalizējas tādās anatomiski sarežǵgitās zonās kā lūpa, acs plakstiņš, auss un deguns.

\subsection{Pētījuma ierobežojumi}

Par dažām lūpas, zoda, acs plakstiņa BŠV ārstēšanas metodēm bija iespējams izdarīt tikai pieņēmumus tendences līmen̄̄, jo (1) kopējais gadījumu skaits nebija pietiekams atšķirību statistiskās ticamības adekvātai novērtēšanai un (2) šīs tendences statistiskai apstiprināšanai būtu nepieciešams veikt padziļinātu pētījumu. 


\section{SECINĀJUMI}

1. Vislielākais bazālo šūnu vēža (BŠV) recidīvu biežums ir pie infiltratīvas klīniski morfologiskās formas, 11-20 mm lieliem audzējiem, lūpas, deguna un acs plakstiņa rajonā; vismazākais recidīvu biežums ir audzējiem, mazākiem par $6 \mathrm{~mm}(<6 \mathrm{~mm})$, kakla vai zoda rajonā. Nav statistiski ticamas sakarības starp pacientu dzimumu un BŠV recidīvu biežumu, bet ir statistiski ticama sakarība ar pacienta vecumu: jo lielāks pacienta vecums, jo retāk pēc ārstēšanas veidojās slimības recidīvi.

2. Staru terapija un lāzerķirurğija ir tikpat efektīvas BŠV ārstēšanai kā operācija. Kriodestrukcija ir vismazāk efektīva ārstēšanas metode.

3. Efektīvākās ārstēšanas metodes virspusēja un nodulāra BŠV ārstēšanai ir operācija, staru terapija un lāzerķirurǵija. Infiltratīva BŠV ārstēšanai efektīva ir operācija. Audzēja izmēru diapazonā līdz $6 \mathrm{~mm}$ efektīvas ir visas darbā apskatîtās ārstēšanas metodes. BŠV ārstēšanai izmēru diapazonā 6-10 mm, 11-20 mm un vairāk kā $20 \mathrm{~mm}$ operācija un staru terapija ir uzskatāamas par efektīvām ārstēšanas metodēm, savukārt lāzerķirurg̣ija un kriodestrukcija ir efektīva tikai noteiktās audzēja lokalizācijās.

4. Faktori, kuri ierobežo (vai pat izslēdz) noteiktu metožu izmantošanu sejas, galvas un kakla BŠV ārstēšanā - staru terapiju: jebkura izmēra un lokalizācijas infiltratīva klīniski morfolog̣iskā BŠV forma; lāzerḳirurǵiju: jebkura izmēra un lokalizācijas infiltratīva klīniski morfologiiskā BŠV forma; jebkura izmēra un jebkuras klīniski morfologiskās formas BŠV auss un lūpas rajonā; kriodestrukciju: jebkura izmēra un lokalizācijas infiltratīva klīniski morfoloǵiskā BŠV forma; jebkuras klīniski morfolog̣iskās formas BŠV auss, lūpas, deguna, pieres vai acs plakstinu rajonā. 
5. Ekspertu vērtējumā labākais kosmētiskais rezultāts ir pēc lāzerḳirurğijas un operācijas; sliktākais kosmētiskais rezultāts ir pēc staru terapijas un kriodestrukcijas.

6. Pētījuma hipotēze ir apstiprināta daḷēji. Hipotēzes daļa, kas attiecas uz ārstēšanas metožu salīdzinājumu (noteiktu sejas, galvas un kakla bazālo šūnu vēža klīniski morfologisko formu, izmēra un precīzi norādītas lokalizācijas gadījumā tādas alternatīvas ārstēšanas metodes kā staru terapija, lāzerķirurğija, kriodestrukcija ir tikpat efektīvas kā tradicionālā ārstēšanas metode - operācija) apstiprinājās. Savukārt hipotēzes daḷa par ādas kosmētisko defektu (rētu) - neapstirpinājās: labākais kosmētiskais rezultāts ir pēc lāzerķirurg̣ijas un operācijas; sliktākais kosmētiskais rezultāts - pēc staru terapijas un kriodestrukcijas. 


\section{PRAKTISKĀS REKOMENDĀCIJAS}

1. Noformējot pacienta medicīnisko dokumentāciju par pirmreizējo sejas, galvas vai kakla BŠV, ir nepieciešams norādīt: audzēja klīniski morfologisko formu; audzēja izmēru; precīzu anatomisko lokalizāciju.

2. Augstāk minēto pazīmju vieglākai aprakstīšanai ir ieteicams lietot autora veidoto "Unificēto primāra ādas vēža slimnieka klīnisku karte".

3. Izvēloties piemērotu ārstēšanas metodi, ir jāṇem vērā audzēju raksturojošo lielumu kopums (klīniski morfoloǵiskā forma, izmēru, precīza anatomiskā lokalizācija), pacienta sociāli demogrāfiskie dati un viņa somatiskais stāvoklis, kā arī vēlmes.

4. Optimālas ārstēšanas metodes izvēlē svarīga ir precīza un adekvāta audzēja diagnostika pirms ārstēšanas uzsākšanas: svarīgi ir noteikt klīniski morfologiisko formu (sevišķu uzmanību pievērošot infiltratīvai formai).

5. Sagaidāmais kosmētiskais rezultāts ir svarīgs kritērijs, izvēloties ārstēšanas metodi, tomēr tas ir otršķiīịs salīdzinājumā ar ārstēšanas metodes efektivitāti. Ir svarīgi to paskaidrot pacientam, ja viṇš izvēlas to ārstēšanas metodi, kas konkrētā pacienta gadījumā būs mazāk efektīva.

6. Piemērotākās ārstēšanas metodes izvēlei, ņemot vērā tādu faktoru kopu kā audzēja klīniski morfologiiskā forma, izmērs, precīza anatomiskā lokalizācija un sagaidāmais kosmētiskais rezultāts, autors ir izveidojis “Ārstēšanas metodes izvēles algoritmu” un "Ārstēšanas kalkulatoru”, kurus rekomendē praktiskai lietošanai. 


\section{PUBLIKĀCIJAS UN ZINOJUMI PAR PẼTİJUMA TËMU \\ Publikācijas (zinātniskie raksti) par pētījuma tēmu}

1. Derjabo A., Cema I., Isajevs S., Donina S. A case report of complicated facial basal cell carcinoma treatment. Acta Chirurgica Latviensis, 2011 $11 / 2156-158$.

2. Thompson M. S., Andersson-Engels S., Svanberg S., Bendsoe N., Palsson S., Derjabo A., Kapostins J., Stenram U., Spigulis J., Svanberg K. Photodynamic therapy of nodular basal cell carcinoma with multifiber contact light delivery. Journal of Environmental Pathology, Toxicology and Oncology 2006, Volume 25 411-424.

3. Griskjans Z., Derjabo A., Cema I. 5-aminolevulinic acid based Photodynamic therapy for basal cell carcinoma: 10-years follow-up after first Latvian experience at Latvian Oncology Center. Stomatologija. Baltic Dental and Maxilofacial Journal 2013 32-36.

4. Derjabo A., Cema I., Lihacova I., Spigulis J. Multispectral imaging method for skin melanoma assessment. Scottish Medical Journal (accepted, in press).

5. Diebele I., Kuzmina I., Kapostinsh J., Derjabo A., Spigulis J. Clinical evaluation of melanomas and common nevi by spectral imaging. Biomedical optics express. 2012 Vol. 3(3) 467-472.

6. Savicka M., Derjabo A., Cema I. Intervention for basal cell carcinoma of the head and neck region. Stomatologija. Baltic Dental and Maxilofacial Journal (accepted, in press)

7. Bekina A., Diebele I., Rubins U., Zaharans J., Derjabo A., Spigulis J. Multispectral assessment of skin malformations by modified videomicroscope. Latvian Journal of Physics and Technical Sciences, 5(49), 2012 4-8. 
8. Diebele I., Kuzmina I., Kapostinsh J., Derjabo A., Spigulis J. Melanoma nevus differentiation by multispectral imaging. SPIE (Society of Photooptical Instrumentation Engineers) - OSA (Optical Society of America) Proceeding - Biomedical Optics, SPIE Vol. 8087, 80872G 2011

9. Diebele I., Bekina A., Derjabo A., Kapostinsh J., Kuzmina I., Spigulis J. Analysis of skin basalioma and melanoma by multispectral imaging. SPIE (Society of Photo-optical Instrumentation Engineers) Proceeding 8427, 8427322012

10. Derjabo A., Cema I., Lihacova I., Derjabo L. 980 nm laser for difficult-totreat basal cell carcinoma. SPIE (Society of Photo-optical Instrumentation Engineers) Proceeding 8803, Medical Laser Applications and Laser-Tissue Interactions VI, 88030B June 24, 2013

11. Lihacova I., Derjabo A., Spigulis J. A multispectral imaging approach for diagnostics of skin pathologies. SPIE (Society of Photo-optical Instrumentation Engineers) Proceeding 8798, Clinical and Biomedical Spectroscopy and Imaging III, 87980X June 18, 2013

\section{Konferenču tēzes par pētījuma tēmu}

1. Derjabo A., Diebele I., Kapostinsh J., Spigulis J. A case report of multispectral imaging for skin cancer assessment. $8^{\text {th }}$ International Young Scientist Conference on Developments in Optics and Communications (DOC 2012) Rīga,12-14.04.2012. Abstract book, 110-111.

2. Derjabo A., Cema I. Long time follow-up results after facial basal cell carcinoma laser treatment in Latvija. European Academy of Dermatology and Venereology $9^{\text {th }}$ Spring Symposium.Verona, Italy 06-10.06.2012 Abstracts on CD-ROM, P191

3. Derjabo A., Cema I., Lihaceva I., Derjabo L. $980 \mathrm{~nm}$ laser for difficult-totreat basal cell carcinoma. European Conferences on Biomedical Optics. 
Society of Photo-optical Instrumentation Engineers (SPIE). Munich, Germany 12-16.05.2013 Abstract book

4. Derjabo A., Cema I., Derjabo L. Is diode laser useful for facial basal cell carcinoma? Baltic Association of Dermatovenereologists Congress. Kaunas, Lietuva 17-19.10.2013

5. Lihacova I., Derjabo A., Bekina A., Zaharans J., Spigulis J. Development of multispectral imaging method for skin pathology diagnostics. Biophotonics - Riga, 26-31.08.2013 Abstract book, 12

6. Diebele I., Bekina A., Derjabo A., Kapostins J., Kuzmina I., Spigulis J. Analysis of skin basalioma and melanoma by multispectral imaging. Society of Photo-optical Instrumentation Engineers (SPIE) Photonics Europe conference. Photonic Solutions for Better Health Care, Brussels, 16-19.04.2012 - SPIE 8427, 842732

\section{Ziṇojumi kongresos un konferencēs}

1. Derjabo A., Thompson M. S., Johansson T., Palsson S., Andersson-Engels S., Svanberg S., Bendsoe N., Kapostins J., Stenram U., Spigulis J., Svanberg K. Photodynamic therapy of basal cell carcinoma. $4^{\text {th }}$ Baltic oncology congress, Tartu Estonia, 25-27.05.2006

2. Derjabo A. Specifics of laser treatment for new growth on eyelids. Regional IALMS conference "Photomedicine 2009: Diagnosis and treatment" $2^{\text {nd }}$ Baltic Association of Laser Medicine Congress, Vilnius, Lietuva, 16.09.2009

3. Derjabo A., Cema I. 10 years follow-up results after facial basal cell carcinoma treatment in Latvia. $7^{\text {th }}$ European Association of DermatoOncology congress Congress, Nantes, France 20-23.06.2011 
4. Derjabo A., Karls R., Ķisis J. Treatment of basal cell carcinoma with imiquimod 5\% cream - results of 3 years follow-up. $7^{\text {th }}$ European Association of Dermato-Oncology Congress, Nantes, France 20-23.06.2011

5. Diebele I., Bekina A., Derjabo A., Kapostins J., Kuzmina I., Spigulis J. Analysis of skin basalioma and melanoma by multispectral imaging. Society of Photo-optical Instrumentation Engineers (SPIE) Photonics Europe conference. Photonic Solutions for Better Health Care, Brussels, $16-19.04 .2012$

6. Derjabo A., Cema I. Long time follow-up results after facial Basal Cell Carcinoma laser treatment in Latvija. European Academy of Dermatology and Venereology $9^{\text {th }}$ Spring Symposium.Verona, Italy 06-10.06.2012

7. Derjabo A., Cema I., Lihaceva I., Derjabo L. $980 \mathrm{~nm}$ laser for difficultto-treat basal cell carcinoma. European Conferences on Biomedical Optics. Society of Photo-optical Instrumentation Engineers (SPIE). Munich, Germany. 12-16.05.2013

8. Derjabo A., Cema I., Derjabo L. Is diode laser useful for facial basal cell carcinoma? Baltic Association of Dermatovenereologists Congress. Kaunas, Lietuva. 17-19.10.2013

9. Derjabo A., Cema I., Derjabo L. Basal cell carcinoma: evaluation of treatment cosmetic results in head and neck region. $12^{\text {th }}$ Joint Symposium Riga-Rostock - Head and Neck Oncology: treatment and reconstruction options. Rīga, 09-10.05.2014

10. Derjabo A., Cema I., Derjabo L. Is so easy to treat facial basal cell carcinoma? XV World Congress on Cancers of the Skin. Edinburgh, Scotland. 03-06.09.2014. 


\section{IZMANTOTĀ LITERATŪRA}

1. Levell N. J., Igali L., Wright K. A., Greenberg D. C. Basal cell carcinoma epidemiology in the UK: the elephant in the room. Clin Exp Dermatol 2013; 38: 367-369.

2. Rowe D. E., Carroll R. J., Day C .L., Jr. Long-term recurrence rates in previously untreated (primary) basal cell carcinoma: implications for patient follow-up. J Dermatol Surg Oncol 1989; 15: 315-328.

3. Silverman M. K., Kopf A. W., Grin C. M. et al. Recurrence rates of treated basal cell carcinomas. Part 1: Overview. J Dermatol Surg Oncol 1991; 17: 713-718.

4. Skellett A. M., Hafiji J., Greenberg D. C. et al. The incidence of basal cell carcinoma in the under-30s in the UK. Clin Exp Dermatol 2012; 37: $227-229$.

5. De Vries E., Micallef R., Brewster D. H. et al. Population-based estimates of the occurrence of multiple vs first primary basal cell carcinomas in 4 European regions. Arch Dermatol 2012; 148: 347-354.

6. Statistikas dati. Onkolog̣ija. Slimību profilakses un kontroles centrs, 2014 http://www.spkc.gov.lv/veselibas-aprupes-statistika/.

7. Basal Cell and Squamous Cell Skin Cancers.Version I.2014. NCCN Clinical Practice Guidelines in Oncology. National Comprehensive Cancer Network www.nccn.org/professionals/physician_gls/pdf/nmsc.pdf.

8. Kim R. H., Armstrong A. W. Nonmelanoma skin cancer. Dermatol Clin. 2012; 30: 125-139.

9. Sartore L., Lancerotto L., Salmaso M. et al. Facial basal cell carcinoma: analysis of recurrence and follow-up strategies. Oncol Rep 2011; 26: $1423-1429$.

10. Nakayama M., Tabuchi K., Nakamura Y., Hara A. Basal cell carcinoma of the head and neck. J Skin Cancer 2011: 496910. 
11. Betti R., Radaelli G., Mussino F. et al. Anatomic location and histopathologic subtype of basal cell carcinomas in adults younger than 40 or 90 and older: any difference? Dermatol Surg 2009; 35: 201-206.

12. Hamm H., Hoger P. H. Skin tumors in childhood. Dtsch Arztebl Int 2011; 108: 347-353.

13. Rhee J. S., Davis-Malesevich M., Logan B. R. et al. Behavior modification and risk perception in patients with nonmelanoma skin cancer. WMJ 2008; 107: 62-68.

14. Skin Cancer Fact Sheet. In. American Academy of Dermatology. 2012.

15. Stafanous S. Five-year cycle of basal cell carcinoma management re-audit. Orbit 2009; 28: 264-269.

16. Skelton L. The effective treatment of basal cell carcinoma. London, Royaume-uni: Allen 2009.

17. Chren M. M., Linos E., Torres J. S. et al. Tumor recurrence 5 years after treatment of cutaneous basal cell carcinoma and squamous cell carcinoma. J Invest Dermatol 2013; 133: 1188-1196.

18. Chren M., Torres J. S., Stuart S. E. et al. Recurrence after treatment of nonmelanoma skin cancer: A prospective cohort study. Arch Dermatol 2011; 147: 540-546.

19. Bath-Hextall F. J., Perkins W., Bong J., Williams H. C. Interventions for basal cell carcinoma of the skin. Cochrane Database Syst Rev 2007; CD003412.

20. Cigna E., Tarallo M., Maruccia M. et al. Basal cell carcinoma: 10 years of experience. J Skin Cancer 2011; 2011: 476362.

21. Dubin N., Kopf A. W. Multivariate risk score for recurrence of cutaneous basal cell carcinomas. Arch Dermatol 1983; 119: 373-377.

22. Goldberg L. H., Rubin H. A. Management of basal cell carcinoma. Which option is best? Postgrad Med 1989; 85: 57-58, 61-53. 
23. Rees J. Choosing treatments for patients: the not so simple case of basal cell carcinoma. Acta Derm Venereol 2009; 89: 450-452.

24. Culleton S., Breen D., Assaad D. et al. 5-year review of a unique multidisciplinary nonmelanoma skin cancer clinic. J Cutan Med Surg 2011; 15: 220-226.

25. Veronese F., Farinelli P., Zavattaro E. et al. Basal cell carcinoma of the head region: therapeutical results of 350 lesions treated with Mohs micrographic surgery. J Eur Acad Dermatol Venereol 2012; 26: 838 - 843.

26. Rodriguez-Vigil T., Vazquez-Lopez F., Perez-Oliva N. Recurrence rates of primary basal cell carcinoma in facial risk areas treated with curettage and electrodesiccation. J Am Acad Dermatol 2007; 56: 91-95.

27. Moesen I., Duncan M., Cates C. et al. Nitrous oxide cryotherapy for primary periocular basal cell carcinoma: outcome at 5 years follow-up. $\mathrm{Br}$ J Ophthalmol 2011; 95: 1679-1681.

28. Tran H. T., Lee R. A., Oganesyan G., Jiang S. B. Single treatment of nonmelanoma skin cancers using a pulsed-dye laser with stacked pulses. Lasers Surg Med 2012; 44: 459-467.

29. Hulyalkar R., Rakkhit T., Garcia-Zuazaga J. The role of radiation therapy in the management of skin cancers. Dermatol Clin 2011; 29: 287-296.

30. Garcia-Martin E., Gil-Arribas L. M., Idoipe M. et al. Comparison of imiquimod 5\% cream versus radiotherapy as treatment for eyelid basal cell carcinoma. Br J Ophthalmol 2011; 95: 1393-1396.

31. Essers B., Nieman F., Prins M. et al. Perceptions of facial aesthetics in surgical patients with basal cell carcinoma. J Eur Acad Dermatol Venereol 2007; 21: 1209-1214.

32. Essers B. A., Nieman F. H., Prins M. H. et al. Determinants of satisfaction with the health state of the facial skin in patients undergoing surgery for facial basal cell carcinoma. Patient Educ Couns 2006; 60: 179-186. 
33. Asgari M. M., Bertenthal D., Sen S. et al. Patient satisfaction after treatment of nonmelanoma skin cancer. Dermatol Surg 2009; 35: 1041-1049.

34. Berridge J. K., Morgan D. A. A comparison of late cosmetic results following two different radiotherapy techniques for treating basal cell carcinoma. Clin Oncol (R Coll Radiol) 1997; 9: 400-402.

35. Thissen M. R., Nieman F. H., Ideler A. H. et al. Cosmetic results of cryosurgery versus surgical excision for primary uncomplicated basal cell carcinomas of the head and neck. Dermatol Surg 2000; 26: 759-764.

36. Maize J. Basal Cell Carcinoma. In Rigel D (ed) Cancer of the skin. Elsevier Health Sciences 2005.

37. Wewers M. E., Lowe N. K. A critical review of visual analogue scales in the measurement of clinical phenomena. Res Nurs Health 1990; 13: 227-236.

38. Teibe U. Biolog̣iskā statistika. Rīga: LU Akadēmiskais apgāds, 2007.

39. Altamura D., Menzies S. W., Argenziano G. et al. Dermatoscopy of basal cell carcinoma: morphologic variability of global and local features and accuracy of diagnosis. J Am Acad Dermatol 2010; 62: 67-75.

40. Ferulova I., Rieba A., Lesins J. et al. Photodiode based prototype device for skin autofluorescence photobleaching diagnostics in dermatology. Lithuanian Journal of Physics 2012; 52.

41. Diebele I., Bekina A., Derjabo A. et al. Analysis of skin basalioma and melanoma by multispectral imaging. In Society of Photo-optical Instrumentation Engineers (SPIE) Photonics Europe conference - Photonic Solutions for Better Health Care. Brussels 2012; 842732.

42. Ulrich M., Lange-Asschenfeldt S., Gonzalez S. Clinical applicability of in vivo reflectance confocal microscopy in dermatology. G Ital Dermatol Venereol 2012; 147: 171-178.

43. Kuflik E. G. Cryosurgery for skin cancer: 30-year experience and cure rates. Dermatol Surg 2004; 30: 297-300. 


\section{PATEICĪBAS}

Vēlos izteikt pateicību manai ğimenei - sievai Ludmilai, meitai Inetai un maniem vecākiem Dmitrijam un Marijai Derjabo. Paldies par palīdzību, atbalstu un mīlestību. Bez Jums šis darbs nebūtu iespējams.

Sirsnīgi pateicos Profesorei Ingrīdai Čēmai, kas palīdzēja šī darba tapšanā, par atbalstu un ieguldīto darbu.

Sirsnīgi pateicos Profesoram Jurijam Kuzminam par komentāriem.

Pateicos Docentam Renāram Ertam par konsultācijām un palīdzību statistisko datu apstrādē.

Paldies Rīgas Austrumu klīniskās universitātes slimnīcas Latvijas Onkologijas centra un RAKUS Ambulatorās daļas ārstiem par atbalstu pētījuma veikšanā.

Pateicos Rīgas Stradiņa universitātei par iegūtajām zināšanām un pieredzi, kas saņemta doktorantūras studiju laikā un par finansiālo atbalstu. Promocijas darbs veikts ar Eiropas sociālā fonda projekta "Atbalsts doktorantiem studiju programmas apguvei un zinātniskā grāda ieguvei Rīgas Stradiṇa universitātē” finansiālu atbalstu (Nr.2009/0147/1DP/1.1.2.1.2/09/IPIA/ VIAA/009). 